\title{
In silico characterization of the global Geobacillus and Parageobacillus secretome
}

\author{
Pedro H. Lebre ${ }^{1}$, Habibu Aliyu ${ }^{2}$, Pieter De Maayer ${ }^{3}$ and Don A. Cowan ${ }^{1 *}$
}

\begin{abstract}
Background: Geobacillus and Parageobacillus are two ecologically diverse thermophilic genera within the phylum Firmicutes. These taxa have long been of biotechnological interest due to their ability to secrete thermostable enzymes and other biomolecules that have direct applications in various industrial and clinical fields. Despite the commercial and industrial interest in these microorganisms, the full scope of the secreted protein, i.e. the secretome, of Geobacillus and Parageobacillus species remains largely unexplored, with most studies focusing on single enzymes. A genome-wide exploration of the global secretome can provide a platform for understanding the extracellular functional "protein cloud" and the roles that secreted proteins play in the survival and adaptation of these biotechnologically relevant organisms.
\end{abstract}

Results: In the present study, the global secretion profile of 64 Geobacillus and Parageobacillus strains, comprising 772 distinct proteins, was predicted using comparative genomic approaches. Thirty-one of these proteins are shared across all strains used in this study and function in cell-wall/membrane biogenesis as well as transport and metabolism of carbohydrates, amino acids and inorganic ions. An analysis of the clustering patterns of the secretomes of the 64 strains according to shared functional orthology revealed a correlation between the secreted profiles of different strains and their phylogeny, with Geobacillus and Parageobacillus species forming two distinct functional clades.

Conclusions: The in silico characterization of the global secretome revealed a metabolically diverse set of secreted proteins, which include proteases, glycoside hydrolases, nutrient binding proteins and toxins.

Keywords: Geobacillus, Parageobacillus, Thermophilic, Global secretome, Comparative genomics, Biotechnological potential

\section{Background}

The genus Geobacillus was first proposed in 2001, where 16S rRNA gene analysis supported the clustering of many thermophilic bacilli into a monophyletic group [1]. More recently, phylogenomic approaches resulted in the division of the genus into two separate genera, Geobacillus and Parageobacillus [2]. Members of these genera are characterized by their thermophilicity, Gram-positive cell wall, and the formation of spores [1]. Due to their ability to sporulate and their catabolic versatility, Geobacillus and Parageobacillus species are cosmopolitan in nature,

\footnotetext{
*Correspondence: don.cowan@up.ac.za

${ }^{1}$ Centre for Microbial Ecology and Genomics, Department of Biochemistry, Genetics and Microbiology, University of Pretoria, Pretoria, South Africa

Full list of author information is available at the end of the article
}

and can be readily isolated from diverse mesophilic and thermophilic environments, including temperate soils, compost, geothermal vents and oil wells [3]. In addition, they are considered attractive targets for biotechnology due to their ability to express and secrete several thermostable enzymes, including proteases, xylanases, lipases, and carboxy-esterases $[4,5]$.

Gram-positive bacteria lack the outer membrane and periplasmic space, where many exported proteins would otherwise be retained, and therefore secrete a large number of proteins that play a significant metabolic role in the adaptation to the ecological niches that they occupy [6, 7]. Bacillus subtilis str. 168, one of the best characterized Gram-positive bacteria, was shown empirically to secrete around 200 extracellular proteins $[8,9]$. A recent in silico study focused on the secretomes of lactic acid bacteria (LABs) predicted that their secretomes

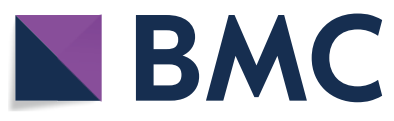

(c) The Author(s) 2018. This article is distributed under the terms of the Creative Commons Attribution 4.0 International License (http://creativecommons.org/licenses/by/4.0/), which permits unrestricted use, distribution, and reproduction in any medium, provided you give appropriate credit to the original author(s) and the source, provide a link to the Creative Commons license, and indicate if changes were made. The Creative Commons Public Domain Dedication waiver (http://creativecommons.org/ publicdomain/zero/1.0/) applies to the data made available in this article, unless otherwise stated. 
can account for as much as $10 \%$ of the proteins encoded on a genome [10]. For the probiotic Bacillus clausii, a large secretome ( $\sim 450$ proteins) could be detected on 2D-SDS PAGE gels [11]. By contrast, there is a relatively little information on the global secretomes of many thermophilic bacteria, despite the known biotechnological advantages of their thermostable enzymes [12-14]. To date, most research has focused on specific thermostable extracellular enzymes, including alpha-amylases from G. stearothermophilus and G. thermoleovorans $[15,16]$, as well as a palm-oil degrading lipase from G. zalihae [17]. However, the development of rapid and inexpensive genome sequencing approaches and the growing number of available genome sequences provide a strong basis for exploring the secretomes of thermophiles. Such studies can facilitate an understanding of how secreted proteins contribute to the adaptation of these microorganisms to their native environments and support the further exploration of thermostable enzymes for biotechnological objectives $[18,19]$. This study presents the first comprehensive in silico analysis of the global secretome of the genera Geobacillus and Parageobacillus.

\section{Results}

\section{Secretion pathways in Geobacillus and Parageobacillus}

The transmembrane translocation of proteins relies on the presence of dedicated secretion pathways [20]. Two of these pathways, namely the sec-dependent and twinarginine dependent (TAT) pathway are common to both Gram-positive and Gram-negative taxa.

The Sec pathway comprises of the proteins SecYEG, which form a membrane-bound channel, the ATPdependent motor protein SecA, the proteins SecD and SecF which maintain a proton motive force for protein export, and the translocase YajC [20]. Furthermore, the foldase PrsA plays a role in the post-translocational folding of extracellular proteins [20]. Comparative genomic analysis of 64 Geobacillus and Parageobacillus genomes (Fig. 1) showed that orthologs of the main components of the Sec pathway are conserved throughout the two genera. Genes encoding SecD, SecF, YajC, and PsrA orthologues were found in the genomes of the 64 compared species.

Conversely, orthologs of the ATPase SecA and translocase SecG genes were absent from the Geobacillus sp. B23 genome, while the genome of $P$. thermoglucosidasius M10EXG did not contain the genes secE and secY. Furthermore, 50 of the compared genomes also contained a gene coding for an alternative ATPase, SecA2, which has been shown to be present in several Gram-positive taxa as part of an alternative Sec pathway for secretion of selected substrates such as large glycosylated lipoproteins [21]. The gene secA2 was found to be absent in all
P. thermoglucosidasius genomes, suggesting that this species does not rely on the alternative Sec pathway for secretion.

The core of the twin-arginine translocation (TAT) pathway in Gram-positive bacteria is the large six membranespanning domain protein $\mathrm{Tat} C$ and the small membrane protein TatA, which together form the channel for secretion of folded proteins [22].The two main operons for Tat pathways in B. subtilis, namely tatAy-tatCy and tatAdtatCd [22], were found in varying degrees of representation across the Geobacillus and Parageobacillus genomes. The tatAy gene was found to be conserved across all genomes, and in 61 strains was found to form an operonic unit with tatCy. This operon has been shown to be constitutively expressed in B. subtilis [22], and its prevalence in the isolates used in this study suggests a similar role in Geobacillus and Parageobacillus for secretion of folded proteins. Conversely, the tat $A$ variant tatAd was found in 55 genomes, only seven of which also contained tatCd. TatAd has been previously described as a bifunctional protein that can substitute for TatAy functionality if the latter is absent [22].

In addition to the Sec and Tat pathways, a number of Geobacillus and Parageobacillus strains were also found to encode a further protein secretion system. This type VII (T7SS) secretion system is associated with toxin secretion in pathogenic bacteria, such as Mycobacterium tuberculosis [23, 24]. T7SS-like secretion systems have also been identified in members of the phylum Firmicutes, including B. subtilis [25]. The B. subtilis T7SS-like system is comprised of a seven gene operon, $y u k \mathrm{E}-y u k \mathrm{D}$ $y u k \mathrm{C}-y u k B A-y u e \mathrm{~B}-y u e \mathrm{C}-y u e \mathrm{D}$, although $y u e \mathrm{D}$ has been shown not to be involved in the secretion system [25]. The T7SS operon, excluding $y u e \mathrm{D}$, was found in eighteen of the 64 compared genomes, comprising three Geobacillus and two Parageobacillus species and including all G. thermodenitrificans and $P$. thermoglucosidasius genomes. The genomes of three strains contain a partial operon, with Geobacillus sp. B4113 and G. icigianus DSM $28325^{\mathrm{T}}$ missing the gene $y u k \mathrm{D}$, while, in Geobacillus sp. B4113 the operon has undergone extensive rearrangements (Fig. 2).

\section{The secretomes of Geobacillus and Parageobacillus}

The secretomes of 49 Geobacillus and 15 Parageobacillus genomes were determined by processing genomederived protein datasets through a secretion prediction pipeline, as described in the methods section. In this study, secretome was defined according to Desvaux et al. [26] as proteins that are secreted extracellularly through specific secretion pathways and do not integrate into the membrane through multiple transmembrane domains (TMs). The secretomes of the 64 isolates 


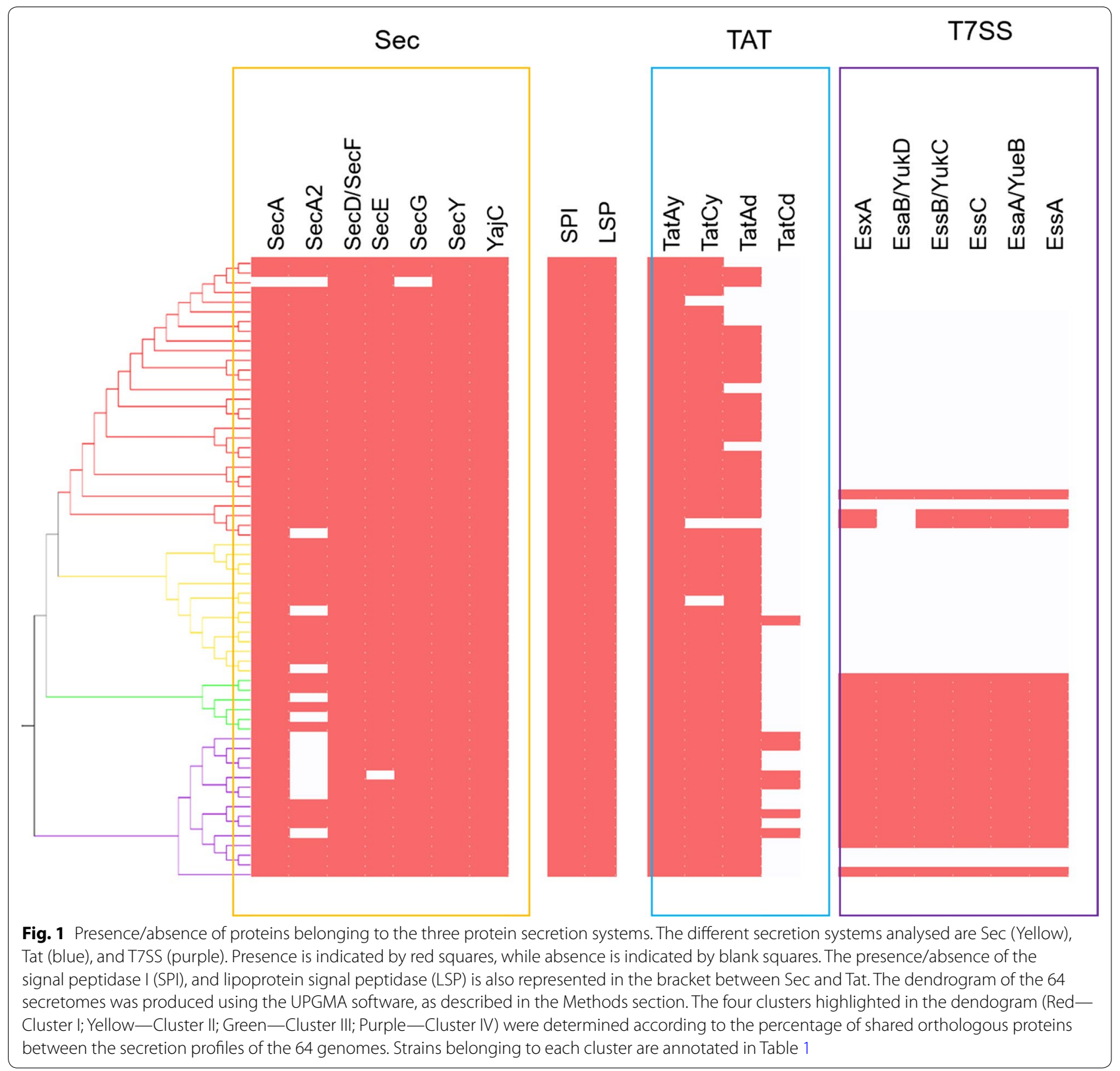

ranged between 114 (G. kaustophilus HTA426; 2.86\% of the total genomic protein content) to 179 (P. thermoglucosidasius DSM $2542^{\mathrm{T}} ; 4.11 \%$ of the total genomic protein content) predicted proteins (Table 1; Fig. 3). The average percentage of secreted proteins across the 64 genomes was calculated as $3.82 \%$ of total genome protein content, and Geobacillus sp. B4109 contained the highest percentage of secreted proteins at $4.78 \%$ of total genome coding DNA sequences (CDSs), which is comparable to the empirically determined secretome of Bacillus subtilis $168(4.79 \%)$ [8, 9], but is substantially smaller than the calculated secretome of the Gram-positive lactic acid bacterium Lactobacillus acidophilus NCFM (10.41\% of total protein content) [10]. The sizes of the secretomes of Geobacillus and Parageobacillus strains were found to be independent of genome size. For instance, Geobacillus sp. $\mathrm{BCO} 2$, which encodes the largest number of proteins on its genome (5233 proteins), was predicted to only secrete $3.04 \%$ of its total protein content, while G. stearothermophilus ATCC $12980^{\mathrm{T}}$, which has the smallest number of proteins encoded on its genome, secretes $3.85 \%$ of the total proteins.

The combinatorial approach used in this study was designed to decrease the number of potential false 


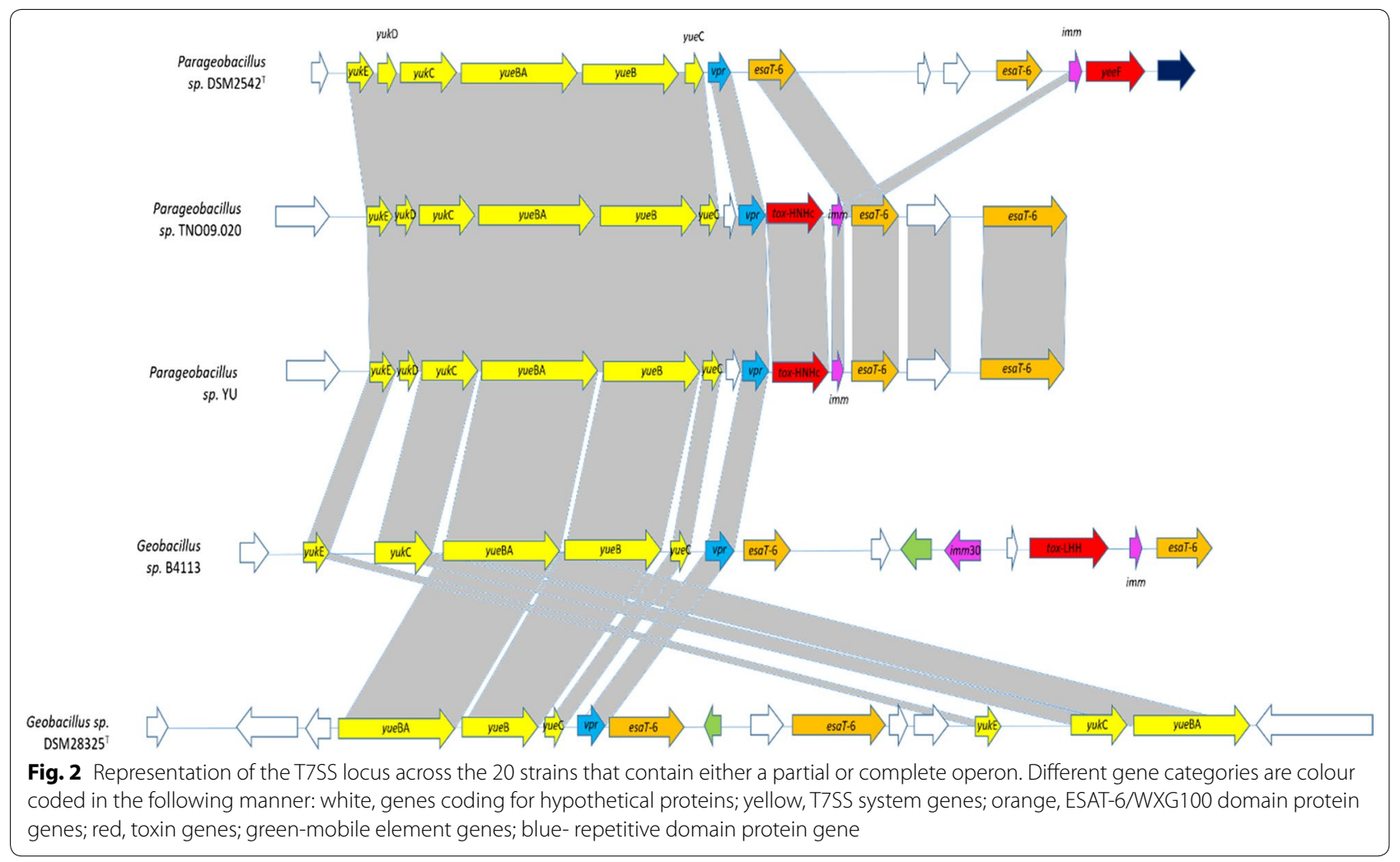

positives in the prediction sets, and the final results yielded lower numbers of predicted proteins than obtained from any secretion prediction method used by itself (data not shown). It is also important to note that prediction methods used for in silico secretome analysis have been shown to overestimate the number of secreted proteins. For instance, $B$. subtilis was predicted to secrete 300 proteins using predictive software, but was shown empirically to secrete close to 200 proteins [9]. Thus, the combinatorial approach used in this study was chosen to mitigate this bias.

\section{The global secretome of Geobacillus and Parageobacillus}

The combined secretome of the 64 Geobacillus and Parageobacillus isolates is comprised of 772 distinct proteins. The proteins in this dataset were classified according to their Conserved Orthologous Group (COG) functional categories (Fig. 4). A total of 438 proteins were functionally annotated and assigned to 18 COG categories, with the largest fraction of the secretome being assigned to proteins of unknown function (S, 38.27\%), followed by carbohydrate transport and metabolism (G, 10.05\%), cell wall/membrane/envelope biogenesis ( $M, 5.82 \%$ ), inorganic ion (P, 4.58\%) and amino acid (E, 5.11\%) transport and metabolism, respectively (Fig. 4).
In terms of signal peptide distribution, 263 proteins (34.06\%) contained a Sec-type signal peptide recognised by type I signal peptidases, while 133 proteins (17.23\%) contained leader peptides with the conserved lipobox signature domain (Fig. 4) [9]. A larger percentage of the global secretome (369 proteins, $47.79 \%$ ) did not have an assigned signal peptide, most of which were present in sequences with no functional annotation. These proteins were predicted as 'secreted' using one of the programs from the prediction pipeline, PsortB, which assigns subcellular localization scores based on structural predictions as well as presence/absence of signal peptides, and therefore is more selective for sequences that do not contain conventional signal peptides [27]. Only four proteins in the entire global secretome contained Tat-specific leader peptides. Twenty-four sequences belonging to the S category were found to contain WXG-type domains, which are specific to the T7SS and T7SS-like secretion systems [24].

The 64 compared isolates were further grouped into four distinct clusters on the basis of the number of shared orthologous proteins (Fig. 5). The largest cluster, cluster I, is composed of twenty-five genomes that include $G$. kaustophilus, G. thermocatenulatus, G. zalihae, G. and jurassicus. Cluster II contains fourteen genomes and is dominated by G. stearothermophilus strains, while 
Table 1 General characteristics of the 64 Geobacillus and Parageobacillus genomes used in this study

\begin{tabular}{|c|c|c|c|c|c|c|c|c|c|}
\hline Species & Strain & Isolation source & Geography & No. of contigs & $\% \mathrm{G}+\mathrm{C}$ & RAST CDSs & $\begin{array}{l}\text { No. } \\
\text { of secreted } \\
\text { CDSs }\end{array}$ & $\begin{array}{l}\% \\
\text { secreted } \\
\text { CDSs }\end{array}$ & Cluster \\
\hline G. kaustophilus & HTA426 & $\begin{array}{l}\text { Deep sea sedi- } \\
\text { ment }\end{array}$ & Mariana Trench & $2(\mathrm{C})$ & 52 & 3986 & 114 & 2.86 & । \\
\hline $\begin{array}{l}\text { G. stearothermo- } \\
\text { philus }\end{array}$ & ATCC 7953 & $\begin{array}{l}\text { Underprocessed } \\
\text { canned food }\end{array}$ & USA & 6 (HQD) & 52.4 & 3283 & 126 & 3.84 & $\|$ \\
\hline Geobacillus sp. & PSS2 & $\begin{array}{l}\text { Dead, steaming } \\
\text { treesm Puhi- } \\
\text { mae thermal } \\
\text { area }\end{array}$ & $\begin{array}{l}\text { Kilauea Volcano, } \\
\text { Hawaii }\end{array}$ & $2(\mathrm{C})$ & 51.6 & 4095 & 128 & 3.13 & 1 \\
\hline Geobacillus sp. & $\mathrm{Et} 2 / 3$ & Geyser & El Tatio, Chile & 12 (HQD) & 49.1 & 3942 & 131 & 3.32 & I \\
\hline Geobacillus sp. & MAS1 & Hot Spring & Pakistan & 5 (HQD) & 52.2 & 4023 & 138 & 3.43 & I \\
\hline Geobacillus sp. & B23 & $\begin{array}{l}\text { Production } \\
\text { water, subter- } \\
\text { ranean oil } \\
\text { reservoir }\end{array}$ & Niigata, Japan & 15 (HQD) & 52.3 & 3718 & 138 & 3.71 & । \\
\hline G.icigianus & B4113_201601 & Mushroom soup & Netherlands & 8 (HQD) & 51.3 & 4156 & 140 & 3.37 & III \\
\hline G. zalihae & NBRC 101842T & $\begin{array}{l}\text { Palm oil mill } \\
\text { effluent }\end{array}$ & Malaysia & $12(\mathrm{HQD})$ & 51.9 & 3960 & 140 & 3.54 & I \\
\hline G. kaustophilus & GBlys & Hot Spring & Japan & 9 (HQD) & 52.1 & 3968 & 143 & 3.60 & I \\
\hline Geobacillus sp. & PSS1 & $\begin{array}{l}\text { Dead, steaming } \\
\text { treesm Puhi- } \\
\text { mae thermal } \\
\text { area }\end{array}$ & $\begin{array}{l}\text { Kilauea Volcano, } \\
\text { Hawaii }\end{array}$ & $1(\mathrm{C})$ & 52.4 & 3733 & 144 & 3.86 & I \\
\hline Geobacillus sp. & C56-T3 & Sandy's Spring & Nevada, USA & $1(\mathrm{C})$ & 52.5 & 3981 & 146 & 3.67 & I \\
\hline Geobacillus sp. & CCB_US3_UF5 & Hot Spring & Perak, Malaysia & $1(\mathrm{C})$ & 52.3 & 3940 & 148 & 3.76 & I \\
\hline $\begin{array}{l}\text { G. thermocatelu- } \\
\text { natus }\end{array}$ & GS-1 & Oil well & China & 9 (HQD) & 52.1 & 3896 & 150 & 3.85 & । \\
\hline G. icigianus & $\begin{array}{c}\text { DSM } 28325 T \\
\text { (G1W1T) }\end{array}$ & Hot Spring & $\begin{array}{l}\text { Baykal, Kam- } \\
\text { chatka, Russian } \\
\text { Fed }\end{array}$ & 9 (HQD) & 52 & 3877 & 150 & 3.87 & III \\
\hline Geobacillus sp. & $\mathrm{GHH} 01$ & $\begin{array}{l}\text { Botanical garden } \\
\text { soil }\end{array}$ & $\begin{array}{l}\text { Hamburg, Ger- } \\
\text { many }\end{array}$ & $1(\mathrm{C})$ & 52.3 & 3947 & 152 & 3.85 & I \\
\hline Geobacillus sp. & C56-T2 & Hot Spring & Nevada, USA & $3(C)$ & 52.4 & 3854 & 153 & 3.97 & III \\
\hline Geobacillus sp. & ZGT-1 & Hot Spring & Jordan & 66 (LQD) & 52.2 & 3894 & 155 & 3.98 & I \\
\hline G. jurassicus & WSUCF1 & Compost & $\begin{array}{l}\text { Washington, } \\
\text { USA }\end{array}$ & 9 (HQD) & 52.2 & 4142 & 158 & 3.81 & I \\
\hline Geobacillus sp. & Et7/4 & Geyser & El Tatio, Chile & 3 (HQD) & 51.7 & 4068 & 158 & 3.88 & I \\
\hline Geobacillus sp. & $\mathrm{BCO} 2$ & $\begin{array}{l}\text { Formation water } \\
\text { of oil well }\end{array}$ & Australia & 13 (HQD) & 52.2 & 5233 & 159 & 3.04 & III \\
\hline Geobacillus sp. & Y412MC52 & Hot Spring & $\begin{array}{l}\text { Yellowstone } \\
\text { National Park, } \\
\text { USA }\end{array}$ & $2(\mathrm{C})$ & 52.3 & 4027 & 159 & 3.95 & । \\
\hline Geobacillus sp. & $\begin{array}{l}\text { DSM 15726T } \\
\text { (NBRC 107829) }\end{array}$ & $\begin{array}{l}\text { High-tempera- } \\
\text { ture petroleum } \\
\text { reservoir }\end{array}$ & Dagang, China & 13 (HQD) & 52.2 & 3872 & 161 & 4.16 & I \\
\hline G. kaustophilus & $\begin{array}{l}\text { DSM 7263T } \\
\quad \text { (NBRC 102445) }\end{array}$ & Pasteurized milk & USA & 7 (HQD) & 52 & 3870 & 161 & 4.16 & I \\
\hline Geobacillus sp. & T6 & Hot Spring & Argentina & 9 (HQD) & 52 & 4071 & 162 & 3.98 & I \\
\hline Geobacillus sp. & CAMR5420 & $\begin{array}{l}\text { CAMR thermo- } \\
\text { phile culture } \\
\text { collection }\end{array}$ & $\begin{array}{l}\text { University of } \\
\text { Bath, UK }\end{array}$ & 11 (HQD) & 51.9 & 3859 & 162 & 4.20 & I \\
\hline Geobacillus sp. & Y4.1MC4 & Hot Spring & $\begin{array}{c}\text { Yellowstone } \\
\text { Bath, USA }\end{array}$ & 19 (HQD) & 52.1 & 3765 & 162 & 4.30 & I \\
\hline $\begin{array}{l}\text { G. thermoleo- } \\
\text { vorans }\end{array}$ & $\begin{array}{l}\text { DSM 5366T } \\
(\text { (KCTC 3570) }\end{array}$ & $\begin{array}{l}\text { soil near hot } \\
\text { water effluent }\end{array}$ & $\begin{array}{l}\text { Pennsylvania, } \\
\text { USA }\end{array}$ & $2(\mathrm{C})$ & 52.3 & 3907 & 163 & 4.17 & I \\
\hline
\end{tabular}


Table 1 (continued)

\begin{tabular}{|c|c|c|c|c|c|c|c|c|c|}
\hline Species & Strain & Isolation source & Geography & No. of contigs & $\% \mathrm{G}+\mathrm{C}$ & RAST CDSs & $\begin{array}{l}\text { No. } \\
\text { of secreted } \\
\text { CDSs }\end{array}$ & $\begin{array}{l}\% \\
\text { secreted } \\
\text { CDSs }\end{array}$ & Cluster \\
\hline Geobacillus sp. & JS12 & Compost & $\begin{array}{l}\text { Namhae, South } \\
\text { Korea }\end{array}$ & $1(\mathrm{C})$ & 52 & 4382 & 165 & 3.77 & 1 \\
\hline Geobacillus sp. & Y412MC61 & Hot Spring & $\begin{array}{l}\text { Yellowstone } \\
\text { National Park, } \\
\text { USA }\end{array}$ & $2(\mathrm{C})$ & 52.3 & 4022 & 166 & 4.13 & 1 \\
\hline $\begin{array}{l}\text { G. stearothermo- } \\
\text { philus }\end{array}$ & ATCC 12980T & $\begin{array}{l}\text { Deteriorated } \\
\text { canned corn } \\
\text { and beans }\end{array}$ & USA & $13(\mathrm{HQD})$ & 53.1 & 3113 & 120 & 3.85 & $\|$ \\
\hline $\begin{array}{l}\text { G. stearothermo- } \\
\text { philus }\end{array}$ & P3 & $\begin{array}{l}\text { Milk powder } \\
\text { manufacturing } \\
\text { plant }\end{array}$ & New Zealand & $21(\mathrm{HQD})$ & 52 & 3703 & 121 & 3.27 & $\|$ \\
\hline Geobacillus sp. & C1BS50MT1 & $\begin{array}{l}\text { water and } \\
\text { sediment from } \\
\text { Great Artesian } \\
\text { Basin gas pro- } \\
\text { ducing bore } \\
\text { well (Below } \\
\text { source) }\end{array}$ & $\begin{array}{l}\text { Queensland, } \\
\text { Australia }\end{array}$ & 21 (HQD) & 52.1 & 3721 & 126 & 3.39 & $\|$ \\
\hline $\begin{array}{l}\text { G. stearothermo- } \\
\text { philus }\end{array}$ & B4114 & $\begin{array}{c}\text { Buttermilk } \\
\text { powder }\end{array}$ & Netherlands & $12(\mathrm{HQD})$ & 52.8 & 3176 & 128 & 4.03 & $\|$ \\
\hline $\begin{array}{l}\text { G. stearothermo- } \\
\text { philus }\end{array}$ & Sah69 & Hot Spring & $\begin{array}{l}\text { Meskoutine, } \\
\text { Algeria }\end{array}$ & $13(\mathrm{HQD})$ & 52.6 & 3470 & 132 & 3.80 & $\|$ \\
\hline $\begin{array}{l}\text { G. stearothermo- } \\
\text { philus }\end{array}$ & A1 & $\begin{array}{l}\text { Milk powder } \\
\text { manufacturing } \\
\text { plant }\end{array}$ & New Zealand & 7 (HQD) & 52 & 3677 & 143 & 3.89 & $\|$ \\
\hline Geobacillus sp. & 12AMOR1 & $\begin{array}{l}\text { Marine hydro- } \\
\text { thermal vent }\end{array}$ & $\begin{array}{l}\text { Troll Wall vent } \\
\text { field, Norway }\end{array}$ & $2(C)$ & 52 & 3864 & 147 & 3.80 & $\|$ \\
\hline Geobacillus sp. & A8 & $\begin{array}{l}\text { Deep mine } \\
\text { water }\end{array}$ & $\begin{array}{l}\text { Limpopo, South } \\
\text { Africa }\end{array}$ & $10(\mathrm{HQD})$ & 52.4 & 3761 & 152 & 4.04 & $\|$ \\
\hline $\begin{array}{l}\text { G. stearothermo- } \\
\text { philus }\end{array}$ & B4109 & Pea soup & Netherlands & $13(\mathrm{HQD})$ & 52.5 & 3308 & 158 & 4.78 & $\|$ \\
\hline Geobacillus sp. & 15 & - & Netherlands & $13(\mathrm{HQD})$ & 52.4 & 3781 & 159 & 4.21 & $\|$ \\
\hline $\begin{array}{l}\text { G. stearothermo- } \\
\text { philus }\end{array}$ & D1 & $\begin{array}{l}\text { Milk powder } \\
\text { manufacturing } \\
\text { plant }\end{array}$ & New Zealand & 5 (HQD) & 52.2 & 3620 & 159 & 4.39 & $\|$ \\
\hline G. zalihae & 53 & Hot Spring & $\begin{array}{c}\text { Garga, Russian } \\
\text { Federation }\end{array}$ & 15 (HQD) & 52.6 & 3628 & 161 & 4.44 & $\|$ \\
\hline Geobacillus sp. & LC300 & $\begin{array}{l}\text { Surface water, } \\
\text { thermophilic } \\
\text { bioreactor }\end{array}$ & USA & $2(\mathrm{C})$ & 52.1 & 4111 & 162 & 3.94 & $\|$ \\
\hline Geobacillus sp. & 22 & Hot Spring & $\begin{array}{l}\text { Garga, Russian } \\
\text { Federation }\end{array}$ & $18(\mathrm{HQD})$ & 52.6 & 3545 & 163 & 4.60 & $\|$ \\
\hline Geobacillus sp. & JF8 & Bark compost & Okayama, Japan & $2(C)$ & 52.8 & 3791 & 142 & 3.75 & III \\
\hline $\begin{array}{l}\text { G. thermodenitri- } \\
\text { ficans }\end{array}$ & $\mathrm{PA}-3$ & Soil & Lithuania & $12(\mathrm{HQD})$ & 48.9 & 4027 & 156 & 3.87 & III \\
\hline $\begin{array}{l}\text { G. thermodenitri- } \\
\text { ficans }\end{array}$ & NG80-2 & $\begin{array}{l}\text { Formation water } \\
\text { of oil well }\end{array}$ & China & $2(C)$ & 48.9 & 3945 & 158 & 4.01 & III \\
\hline $\begin{array}{l}\text { G. thermodenitri- } \\
\text { ficans }\end{array}$ & DSM 465T & Sugar beet juice & Austria & $12(\mathrm{HQD})$ & 49.1 & 3692 & 158 & 4.28 & III \\
\hline $\begin{array}{l}\text { G. thermodenitri- } \\
\text { ficans }\end{array}$ & G11MC16 & Grass compost & USA & 8 (HQD) & 48.8 & 3997 & 167 & 4.18 & III \\
\hline G. subterraneus & $\begin{array}{l}\text { DSM 13552T } \\
\text { (KCTC 3922) }\end{array}$ & Oil field & Liaohe, China & $1(\mathrm{C})$ & 52.2 & 3758 & 176 & 4.68 & III \\
\hline $\begin{array}{l}\text { Parageobacil- } \\
\text { lus sp. }\end{array}$ & NUB3621 & Soil & China & $1(\mathrm{C})$ & 44.4 & 3914 & 131 & 3.35 & IV \\
\hline P. toebii & WCH70 & Compost & USA & 3 (HQD) & 42.8 & 3785 & 137 & 3.62 & IV \\
\hline
\end{tabular}


Table 1 (continued)

\begin{tabular}{|c|c|c|c|c|c|c|c|c|c|}
\hline Species & Strain & Isolation source & Geography & No. of contigs & $\% G+C$ & RAST CDSs & $\begin{array}{l}\text { No. } \\
\text { of secreted } \\
\text { CDSs }\end{array}$ & $\begin{array}{l}\% \\
\text { secreted } \\
\text { CDSs }\end{array}$ & Cluster \\
\hline $\begin{array}{l}\text { P. thermoglucosi- } \\
\text { dasius }\end{array}$ & Y4.1MC1 & Hot Spring & $\begin{array}{l}\text { Yellowstone } \\
\text { National Park, } \\
\text { USA }\end{array}$ & $2(C)$ & 44 & 4457 & 138 & 3.10 & IV \\
\hline $\begin{array}{l}\text { P. caldoxylosi- } \\
\text { lyticus }\end{array}$ & $\mathrm{ClC9}$ & Hot Spring & Indonesia & $6(\mathrm{HQD})$ & 44.2 & 4116 & 139 & 3.38 & IV \\
\hline $\begin{array}{l}\text { P. thermoant- } \\
\text { arcticus }\end{array}$ & M1T & Geothermal soil & Antarctica & 9 (HQD) & 43.7 & 3883 & 142 & 3.66 & IV \\
\hline $\begin{array}{l}\text { P. caldoxylosi- } \\
\text { lyticus }\end{array}$ & $\begin{array}{l}\text { DSM 12041T } \\
\quad \text { (NBRC 107762) }\end{array}$ & Soil & Australia & 14 (HQD) & 43.9 & 4130 & 147 & 3.56 & IV \\
\hline $\begin{array}{l}\text { P. thermoglucosi- } \\
\text { dasius }\end{array}$ & C56YS93 & Hot Spring & Obsidian, USA & $3(C)$ & 43.9 & 4569 & 148 & 3.24 & IV \\
\hline P. toebii & B4110 & Pea soup & Netherlands & 8 (HQD) & 42.2 & 3912 & 148 & 3.78 & IV \\
\hline $\begin{array}{l}\text { P. caldoxylosi- } \\
\text { lyticus }\end{array}$ & B4119 & Food & Netherlands & 18 (HQD) & 44 & 4367 & 151 & 3.46 & IV \\
\hline $\begin{array}{l}\text { P. thermoglucosi- } \\
\text { dasius }\end{array}$ & YU & Dairy & Netherlands & 24 (HQD) & 43.8 & 4320 & 151 & 3.50 & IV \\
\hline $\begin{array}{l}\text { P. thermoglucosi- } \\
\text { dasius }\end{array}$ & TNO09.20 & $\begin{array}{l}\text { Dairy factory } \\
\text { biofilm }\end{array}$ & Netherlands & $1(\mathrm{C})$ & 43.9 & 4282 & 151 & 3.53 & IV \\
\hline $\begin{array}{l}\text { P. thermoglucosi- } \\
\text { dasius }\end{array}$ & M10EXG & Waste compost & Australia & $1(\mathrm{C})$ & 43.7 & 4301 & 156 & 3.63 & IV \\
\hline $\begin{array}{l}\text { P. thermoglucosi- } \\
\text { dasius }\end{array}$ & B4168 & $\begin{array}{l}\text { Dairy processing } \\
\text { environment }\end{array}$ & Netherlands & 17 (HQD) & 43.8 & 4233 & 157 & 3.71 & IV \\
\hline P. toebii & $\begin{array}{l}\text { DSM 14590T } \\
\quad \text { (NBRC 107807) }\end{array}$ & Hay compost & Korea & $3(C)$ & 42.1 & 3580 & 166 & 4.64 & IV \\
\hline $\begin{array}{l}\text { P. thermoglucosi- } \\
\text { dasius }\end{array}$ & DSM $2542 T$ & Soil & Kyoto, Japan & $1(\mathrm{C})$ & 43.9 & 4354 & 179 & 4.11 & IV \\
\hline
\end{tabular}

The number of contigs for each genome are categorized using the following categories: C, complete genome; HQD, high quality draft; LQD, low quality draft

cluster III is the smallest with ten genomes that include G. thermodenitrificans, G. icigianus and G. subterraneus. Members of the genus Parageobacillus form a distinct cluster, cluster IV, with fifteen genomes that included $P$. caldoxylosilyticus, P. toebii, P. thermoglucosidasius, and $P$. thermoantarcticus strains (Table 1).

\section{A minimal core secretome is conserved among Geobacillus and Parageobacillus species}

A comparison of the groups of orthologues shared within and between the clusters showed that a total of only thirty-one proteins ( $4.14 \%$ of the global secretome) have orthologs in all Geobacillus and Parageobacillus genomes. This low number of core proteins reflects the high degree of functional variability between the clusters. Similarly, the number of shared orthologs within each cluster was proportional to the number of strains in that cluster, with clusters III and IV containing the lowest number of shared orthologs (54 and 46 proteins, respectively), followed by cluster II (62 proteins), and cluster I (63 proteins). The clustering of the secretomes according to number of shared proteins also conserves the phylogenetic groups previously determined by Aliyu et al. [2]
(Fig. 6, Additional file 1: Table S1), with many of the species clades retaining the same architecture.

The core secretome was largely dominated by proteins in the COG functional categories of cell wall biogenesis and sporulation, proteins involved in nutrient scavenging and transport across the cell wall/membrane, and proteins of unknown function. Cell wall biogenesis/sporulation proteins include several carboxypeptidases such as the spore cortex lytic enzyme SleB and two DL-endopeptidases, CwlO and LytE, which are involved in the cleavage of the peptidoglycan stem peptide during different growth stages [28, 29]. Other hydrolases present in the core secretome included the autolysins SpoIID and SpoIIP, which are required for septal hydrolysis during the sporulation process [30]. In addition, the putative gamma-glutamyl transferase YwrD, which is also part of the core protein set, has been hypothesised to be involved in amino acid transport into the cell and in glutathione metabolism due to its orthology to the gamma-glutamyl transpeptidase Ggt [31]. Alternately, YwrD in Geobacillus and Parageobacillus might play a similar role to the gammaglutamyl transferase in B. subtilis, which is involved in 


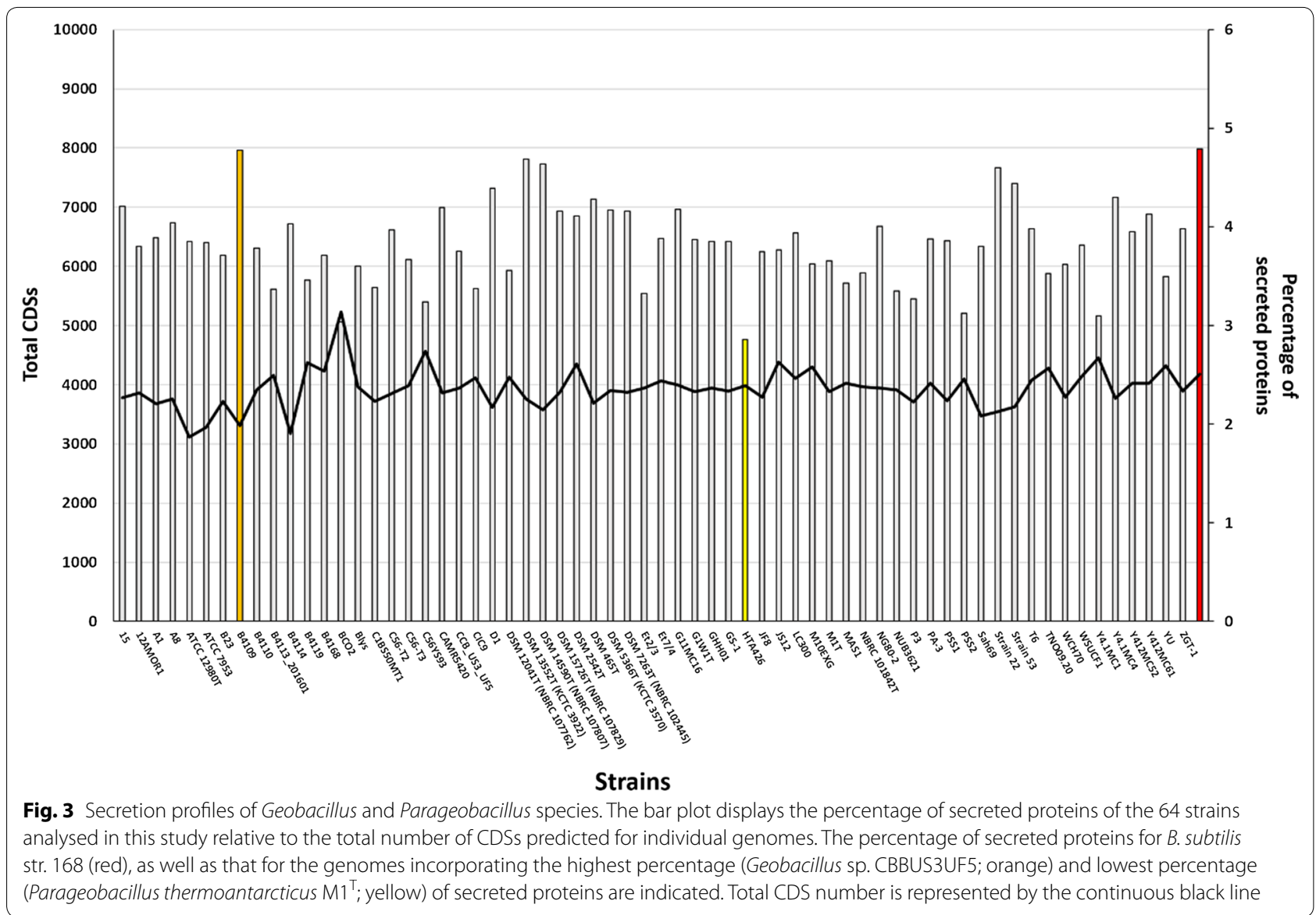

the degradation of the poly-gamma-glutamate capsule [32]. However, the nature of the capsule in Geobacillus and Parageobacillus could not be inferred from the secretome data, and therefore it is uncertain whether YwrD plays a role in its formation.

\section{Metabolic capabilities of the Geobacillus and Parageobacillus secretome}

To further assess the function of the global secretome, the annotated protein fraction was screened for specific functions and domains using KAAS (KEGG Automatic Annotation Server) [33], SMART (Simple Modular Architecture Research Tool) [34], Uniprot [35], CAZy (carbohydrate-active enzyme) [36], CDD (Conserved Domains Database) [37] and TCDB (Transporter Classification Database) [38] databases. The global secretome was found to harbour a large number of functional protein families, which include glycoside hydrolases, lipases, proteases, nucleases and toxins (Additional file 2: Tables S2, S3).

\section{Adaptations to environmental constraints}

Functional analysis of the global secretome of Geobacillus and Parageobacillus revealed the presence of proteins involved in the general adaptation to thermophilic environments. These include substrate-binding proteins from the ATP-binding cassette $(A B C)$ superfamily [39] that support heterotrophic growth on a range of organic and inorganic substrates (Fig. 7). Of note is the prevalence of SBPs for nitrate/sulfonate/bicarbonate (3.A.1.17.2) as well as iron (III) (3.A.1.14.9), which are used as electron acceptors during anaerobic respiration.

SBPs for trehalose and maltose (3.A.1.1.41) and glycine betaine (3.A.1.12.11) were found to be prevalent in genomes from clusters I, II, and III. These compatible solutes play a crucial role in the general adaptive strategy of xerotolerant micro-organisms due to their ability of reduce intracellular viscosity through vitrification, therefore inhibiting membrane and protein disruption caused by lack of intracellular water [40, 41]. An SBP which is specific for the polyamines spermidine and spermine (3.A.1.11.8) is prevalent in all species from cluster $\mathrm{IV}$, as well as G. jurassicus and G. thermodenitrificans. These organic compounds prevent thermal inactivation 


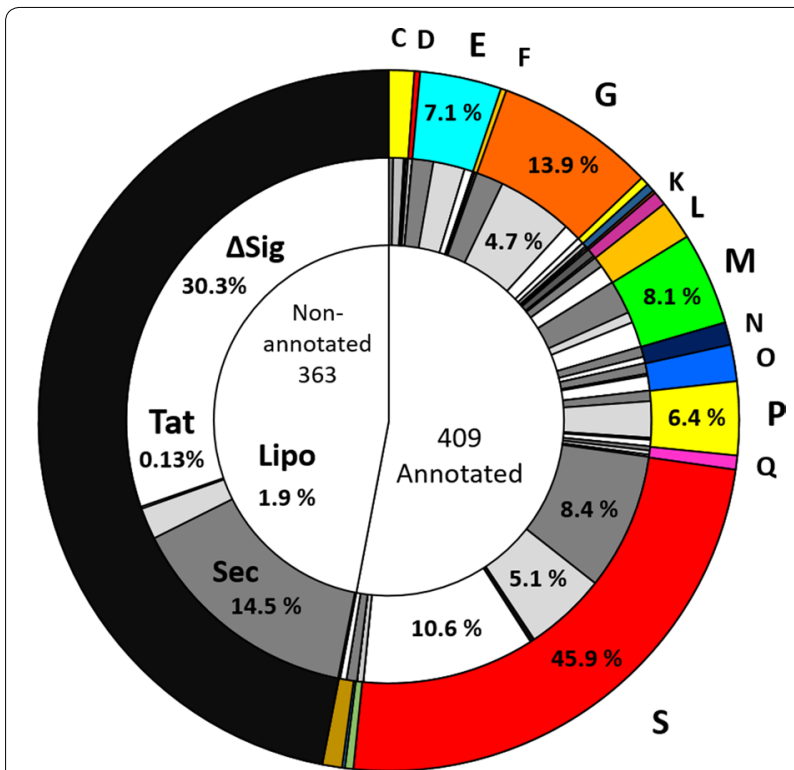

Fig. 4 Functional annotation of the global secretome. The inner circle indicates the proportion of annotated and non-annotated proteins in the global secretome. The middle circle shows the distribution of different types of signal peptides across the annotated and non-annotated portions of the global secretome, with a focus on signal peptide percentages within the different COG categories: Sec (dark grey), Sec-type Type I SPase signal peptide; Lipo (light grey), Lipoprotein Type II SPase signal peptide; TAT (black), Twin-arginine type signal peptide; $\Delta$ Sig (white), no signal peptide. The outer circle shows the distribution of annotated proteins across the different COG categories: C (energy production and conversion); E (amino acid transport and metabolism); G (carbohydrate transport and metabolism); K (transcription); L (replication/recombination and repair); M (cell wall/membrane/envelope biogenesis); N (cell motility); $\mathrm{O}$ (post-translational modification/protein turnover/chaperones); $\mathrm{P}$ (Inorganic ion transport and metabolism); Q (secondary metabolites biosynthesis, transport, and catabolism); S (function unknown); $V$ (defence mechanisms)

of DNA and ribosomes, and have previously been associated with thermo-adaptation traits in Geobacillus species [42]. Another protein belonging to the Hsp20/alpha crystalline family of heat-shock proteins (WP_033014044.1) was found in the secretion profiles of 60 strains.

Screening using the dbCAN database [36] identified 51 distinct proteins with glycoside hydrolase (GH) domains (Additional file 3: Figure S1), which include enzymes involved in the degradation of complex polysaccharides from plant cell wall, hemicellulose, cellulose and pectin. The hemicellulose degradation locus has been extensively characterized in G. stearothermophilus T6 [43], and was shown to be a prevalent and versatile feature in Geobacillus and Parageobacillus species [5, 44]. This locus includes a gene coding for the GH family 10 xylanase XynA1 which degrades the xylan backbone

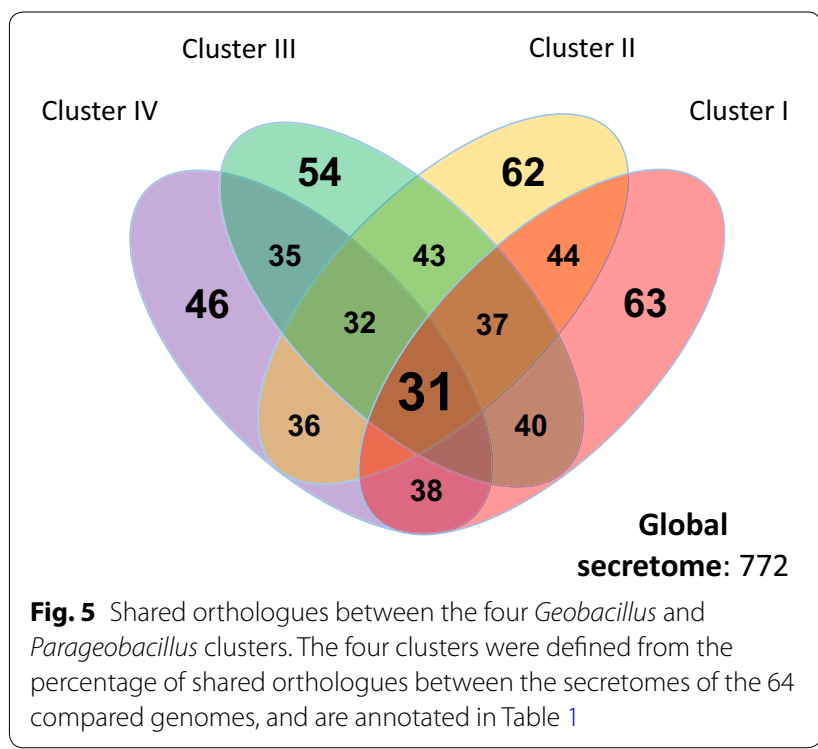

into xylooligosaccharides before transport across the cell membrane [45]. In the present study, XynA1 (WP_044731438) was detected in 23 Geobacillus (sixteen from cluster I) and two Parageobacillus genomes, in all cases coinciding with the presence of an SBP for xylo-oligosaccharides (3.A.1.1.9).

The global secretome was also found to contain putative polymorphic proteins that could be involved in intra- and inter-species competition in crowded microbial communities. In particular six WXG-type proteins with distinct toxin domains were detected across sixteen of the genomes that contained either the complete or partial T7SS locus. Analysis using the CDD database and SMART revealed that these putative toxins shared the same domain architecture with a highly conserved N-terminus WXG100 secretion domain (PF06013) and linker pre-toxin (PT-TG) domain, as well as a hypervariable C-terminal region containing the toxin domain. Of the six putative toxins, four contain nuclease-fold $\mathrm{C}$-terminal domains, including the RNase Ntox50 (PF15542), as well the tox-SHH (PF15652), -GHH (IPR028916), and $-\mathrm{AHH} \mathrm{HNH} /$ EndoVII domains. These have been recently identified as members of a novel superfamily of diffusible polymorphic toxins that act by non-specific nucleotide degradation after transport across the cell wall of the target host [46]. In addition, one putative toxin (WP_003248146.1) in the dataset also contains a C-terminal colicin-like bacteriocin domain (PF12639), which also has endonuclease activity [47, 48]. These putative toxins were found to be more prevalent in $P$. thermoglucosidasius secretomes, with $P$. thermoglucosidasius TNO09.020, P. thermoglucosidasius YU, and P. 


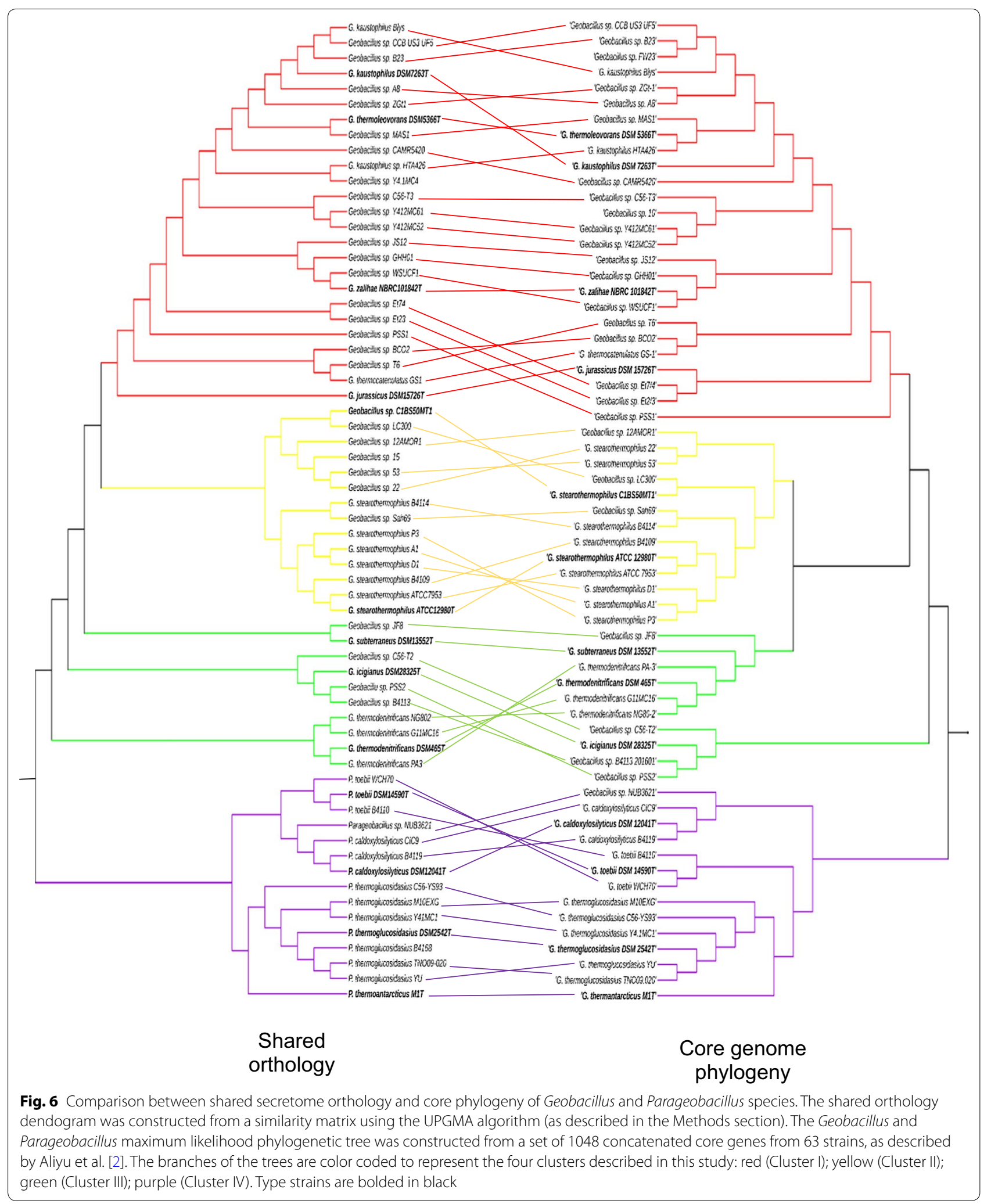




\section{Frequency of gene occurrence within species:}

\begin{tabular}{|l|l|l|l|l|}
0.2 & 0.4 & 0.6 & 0.8 & 1
\end{tabular}

SBP substrate

protocatechuate $(3,4-$

dihydroxybenzoate)

5-6 amino acyl oligopeptide (lipo)

aldotetraouronic acid/xylo-

oligosaccharide

Aldouronate

C4-dicarboxylate

cysteine

D-ribose

ectoine/hydroxyectoine

fumarate/D- and L-malate

Glucose

glutamine/glutamate/aspartate

glutathione

glycerol-3-phosphate

glycine/betaine

hydroxamate siderophore

Inositol phosphate

iron

Iron (II)-hydroxamate

lactose

L-cystine (lipo)

methionine

nickel/depeptide/oligopeptide

nitrate/sulfonate/bicarbonate

pentose/hexone

phosphate

raffinose/stachyose

siderophore-iron binding

Spermidine/putrescine

sulfonate

taurine

trehalose/maltose

Trehalose/sucrose

tryptophan

urea

xylo-oligosacharides
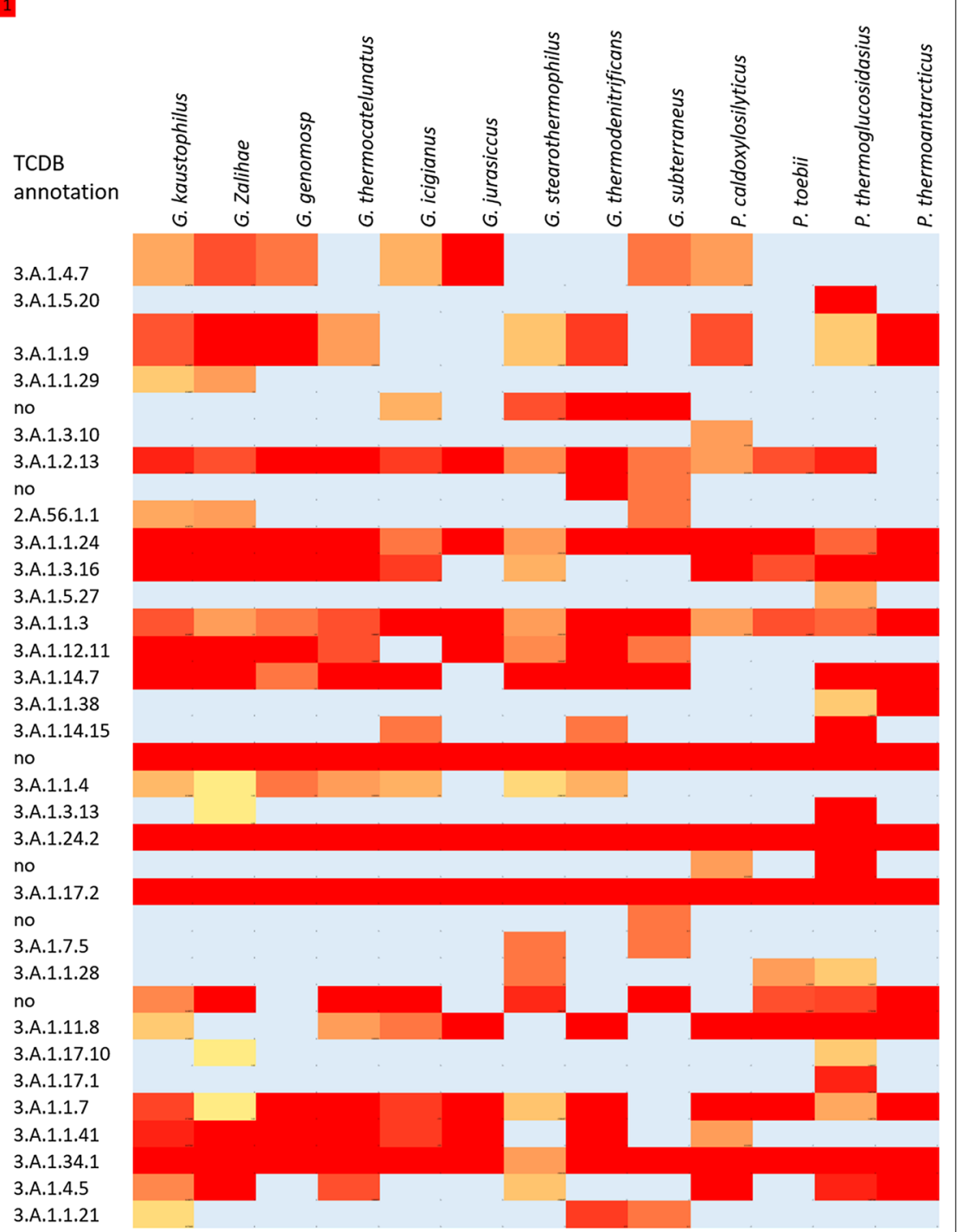

Fig. 7 Heat map of SBPs' presence across the different Geobacillus and Parageobacillus species. The heat map was constructed using the 64 genomes listed in Table 1. Frequency of gene occurrence was determined as the number of secretion profiles within a species that share the same gene divided by the number of genomes from that species

thermoglucosidasius C56-YS93 containing three proteins with colicin, tox-GHH, Ntox37 domains.

\section{Biotechnologically relevant proteins}

In addition to the proteins described above, the functional characterization of the global secretome revealed the presence of putative proteins with significant homology to biotechnologically relevant enzymes. This included a GH3 family putative beta- $N$-acetylhexosaminidase (WP_033018107.1), which was detected in seventeen genomes in clusters III and IV. This protein is orthologous to NagZ from B. subtilis, which has catalytic activity against xylans as well as chitin [49]. Another putative xylanase-chitin deacetylase (WP_066233069.1) containing a domain with homology to the NodB chitooligosaccharide deacetylase domain from Rhizobium [50], was found to be shared by 41 genomes.

The protein Abp (EPR29279.1), a GH27 family betaL-arabinopyranosidase involved in the digestion of arabino-polysaccharides [51], was found to be present in 


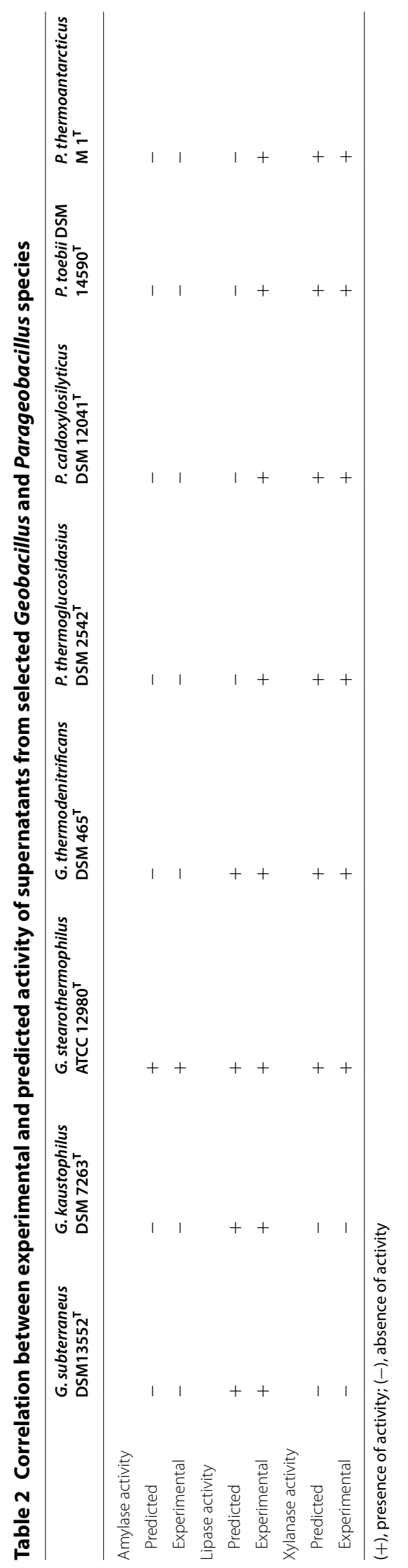


nine Geobacillus strains, as was a putative GH53 family endo-beta-1,4-galactanase (GAD13376.1) with 98.6\% average amino acid identity with GanB from G. stearothermophilus. This protein, which is involved in the degradation of the galactan side chains of pectin [52], forms part of the secretome of eight strains in clusters I and III.

Alpha-amylases hydrolyse alpha-D-glucosidic linkages in complex polysaccharides such as starch and glycogen, and are widely used in detergents, starch modification in the paper industry, and the production of ethanol as a liquid biofuel [53]. Screening of the global secretome for proteins with the alpha-amylase domain $\mathrm{GH} 13$ revealed that twenty-four strains from clusters I, II, and III are predicted to secrete a large amylopullulanase (KYD25568.1) with high sequence homology to Apu from G. thermoleovorans, which shows high affinity to pullulan and amylopectin [54]. Twenty-one strains from the same three clusters contain orthologues of the alpha-amylase AmyS from G. stearothermophilus (WP_080706509.1) [55]. In addition, a putative GH13 hydrolase (WP_042408692.1) was found in P. caldoxylosilyticus DSM12041 ${ }^{\mathrm{T}}, P$. caldoxylosilyticus B4119, P. toebii WCH70, and G. subterraneus DSM $13552^{\mathrm{T}}$ with $38 \%$ average amino acid identity to the maltogenic alpha-amylase Novamyl, which is used as an anti-staling agent [56].

Lipases and carboxylesterases are versatile enzymes that catalyse both the hydrolysis and esterification of lipids, under aqueous and non-aqueous conditions, respectively, making them essential enzymes for cell membrane recycling and conversion of non-metabolizable polysaccharides [57]. These enzymes also hold a large percentage of the industrial enzyme market, and are used in a number of industrial processes, from conversion of palm oil into high value cosmetic and food components, oil removal in detergents and other cleaning products and transesterification of vegetable oils to biodiesel [58, 59]. Two different lipolytic enzymes were identified in the global secretome, both of which were found to be restricted to members of the genus Geobacillus used in this study. A lipase (KZE97058.1) sharing 95\% average amino acid identity with a thermolipase from Bacillus sp. 42 forms part of the secretome of 44 Geobacillus strains in clusters I-III. The Bacillus sp. 42 orthologue functions optimally at $70{ }^{\circ} \mathrm{C}$ and tolerant to various polar organic solvents such as DSMO and ethanol, which makes it a potential biocatalyst for biodiesel production [60]. Furthermore, orthologues of a GDSL- family carboxylesterase from $G$. thermodenitrificans $\mathrm{T} 2$, which hydrolyses short-chain ester substrates, were found in 57 secretomes from the four clusters.

Proteases play vital roles in many physiological processes such cell wall biogenesis, quality control of secreted proteins, the degradation of oligopeptides into amino acids that are transported intracellularly, cell viability and pathogenicity [61, 62]. Screening the secretome against the MEROPS database [63] revealed two proteases with orthology to biotechnologicallyrelevant biocatalysts. The first is a thermostable neutral protease (AKM20115.1) that is present in the secretomes of 48 compared strains across the four clusters. This protein shares $72.5 \%$ average amino acid identity with Thermolysin from G. stearothermophilus, which is used commercially in the production of the artificial sweetener aspartame [4]. The second is an S8 family alkaline serine protease (WP_008881971.1), found in eleven secretomes across Clusters III and IV, sharing 41.0\% amino acid sequence identity with Subtilisin BPN' from B. amyloliquefaciens, which is used as a detergent additive [64].

\section{Correlation between predicted and experimental data}

To assess the accuracy of the predictive pipeline used in this study, a selection of Geobacillus and Parageobacillus type strains were experimentally assayed for selected activities of secreted enzymes in spent cultivation medium supernatant. Table 2 shows the correlation between the predicted and experimental results for $\alpha$-amylase, xylanase, and lipase/eterase activities across the eight type strains tested.

The ability of the different type strains to degrade oat spelt xylan was found to exactly correlate with the presence or absence of xylan-degrading hydrolases in the predicted secretome. G. thermodenitrificans DSM $465^{\mathrm{T}}$, which was predicted to contain the GH family 10 xylanase XynA1as well as the beta- $N$-acetylhexosaminidase discussed above, exhibited the highest activity (33.78 nkat.ml ${ }^{-1}$, Additional file 4: Figure S2). By comparison, $P$. thermoglucosidasius DSM $2542^{\mathrm{T}}$ and $P$. thermoantarcticus $\mathrm{M} 1^{\mathrm{T}}$, which lack either XynA1 or the beta- $\mathrm{N}$-acetylhexosaminidase respectively, exhibited significantly lower activity (10.67 nkat $\mathrm{ml}^{-1}$ and 15.99 nkat $\mathrm{ml}^{-1}$, respectively). Surprisingly $P$. caldoxylosilyticus DSM $12041^{\mathrm{T}}$ exhibited very low activity $\left(1.74 \mathrm{nkat} \mathrm{ml}^{-1}\right)$, despite secreting the same xylan-degrading enzymes as $P$. thermoglucosidasius. Interestingly, both G. stearothermophilus ATCC 12980 T and P. toebii DSM $14590^{\mathrm{T}}$ exhibited xylan-degrading activity against oat spelt xylan, despite lacking the genes for XynA1 and the NagZ deacetylase orthologue. Both strains share the putative extracellular xylanase-chitin deacetylase (WP_066233069.1) that is present across 41 secretion profiles of the four clusters.

Similarly, $\alpha$-amylase plate activity assays (Additional file 5: Figure S3) reflected the predicted distribution of this enzyme. Of the eight strains tested, only G. stearothermophilus ATCC $12980^{\mathrm{T}}$, which is predicted to 
encode an $\alpha$-amylase (WP_080706509.1) showed activity against starch.

Lipolytic activity was determined by means of p-nitrophenyl butyrate (PNPB) degradation assays. All eight tested strains exhibited varying degrees of activity against PNPB (Additional file 6: Figure S4). Two of the four strains predicted to secrete a lipase (KZE97058.1), G. kaustophilus DSM $7263^{\mathrm{T}}$ and G. stearothermophilus ATCC $12980^{\mathrm{T}}$, showed high rates of activity (83.82 and $56.86 \mathrm{U} \mathrm{ml}^{-1}$, respectively), while the two other Geobacillus strains exhibited comparatively lower activities. None of the Parageobacillus strains used in the assays were predicted to secrete a lipase. However, some lipolytic activity could be observed for the assays with $P$. caldoxylosilyticus, $P$. toebii and $P$. thermoglucosidasius. This activity may explained by the presence of an extracellular GDSL-family carboxylesterase, noting that many carboxylesterases can hydrolyse PNPB. However, P. thermoantarcticus $M 1^{\mathrm{T}}$ was not predicted to secrete either lipases or carboxylesterases. A orthologue of the carboxylesterase is present in the genome of $P$. thermoantarcticus, but this enzyme lacks the signal peptides required for secretion. It cannot be excluded, however, that this carboxylesterase may be secreted through non-classical pathways.

\section{Discussion}

Geobacillus and Parageobacillus are cosmopolitan Grampositive taxa that are able to tolerate the multiple abiotic stresses in the biomes in which they are found (Table 1). Some of the characteristic 'extreme' conditions of such biomes include elevated temperatures, desiccation (e.g. desert soils), extremes of $\mathrm{pH}$ and high salinity (e.g. saline playas) and metal-induced toxicity (e.g. hydrothermal vents) [65]. The identification and analysis of the secretomes of these bacteria might therefore contribute to an understanding of how they adapt to such a broad range of environmental stresses.

It has previously hypothesized that sporulation is the main contributing factor to the dispersal and survival of Geobacillus across a wide range of biomes [3]. The concept of sporulation as a universal survival strategy is corroborated by the prevalence of sporulation-related carboxypeptidases and cortex-lytic proteins in the core secretome of Geobacillus and Parageobacillus. However, evidence for additional stress tolerance mechanisms associated with thermophiles can also be found in the global secretome. An extracellular iron/manganese superoxide dismutase, which is found in the 64 Geobacillus and Parageobacillus genomes, is involved in the scavenging toxic reactive oxygen species (ROS) produced by many heterotrophic bacteria as a by-product of the catalytic activity of $\mathrm{NAD}(\mathrm{P}) \mathrm{H}$ oxidoreductases [66]. Additionally, SBPs for compatible solutes found across most
Geobacillus and Parageobacillus genomes suggest that these play an important role in survival during periods of extreme heat and desiccation.

The metabolic signatures found in the global secretome also suggest that Geobacillus and Parageobacillus are metabolic versatile bacteria with the capacity to utilize a large range of monosaccharide and polysaccharide substrates Additionally, the secretome suggested that Geobacillus and Parageobacillus have the capacity to perform anaerobic respiration using iron, nitrates and sulphates as electron acceptors. Geobacillus and Parageobacillus might thus employ an versatile opportunistic survival strategy, in which cells are able to rapidly switch from a dormant spore state to an actively growing phase.

Conversely, the secretion profiles of Geobacillus and Parageobacillus species were found to be highly heterogeneous, even within the same species. This functional heterogeneity across and within each genus is not surprising, considering the diversity of ecological niches from which the strains have been isolated. Alternately, the fact that the clustering of strains according to shared percentage of protein orthologues preserved the phylogenetic clustering at species and genus levels suggests that the secretomes of Geobacillus and Parageobacillus species are composed of a significant share of genes that have been vertically maintained through the evolutionary speciation process. It is important to note that while the genomes used in this study exhibit different levels of completeness, they were carefully selected on the basis of assembly status, with genomes of inferior quality being excluded. Thus, we argue that the functional heterogeneity described in this study represents a good approximation of the true genetic differences between strains rather than a bias created by the addition of incomplete genomes.

The global secretome of Geobacillus and Parageobacillus is of likely interest in several biotechnology sectors due to the ability of these organisms to secrete a wide range of thermostable biocatalysts [67]. Examples include the well-characterized XynA1 from G. stearothermophilus, which has been implicated in the production of second-generation biofuels from plant biomass [68]. This study has revealed several other, yet uncharacterized, proteins with significant orthology to potentially useful biocatalysts (Additional file 7: Table S3). For instance, analysis of the global secretome revealed the presence of uncharacterized WXG100-type polymorphic toxins in Parageobacillus species and the closely related G. thermodenitrificans. These bacteriocins might represent targets as novel antimicrobial agents, particularly in the food industry where thermostability is a desirable trait to prevent pathogen persistence during the preservation process [69]. 
It is worth noting that a significant percentage of proteins in the global secretome ( $46.07 \%$ of the dataset) are hypothetical or have no significant homology to domains and sequences in the databases used in this study. The presence of these secreted "dark matter" proteins highlights the fact that Geobacillus and Parageobacillus biology is still largely unexplored and has the capacity to reveal novel traits and functions and products of biotechnological value.

The experimental assays performed in this study validate the predictive pipeline used for the analysis of the global secretome of Geobacillus and Parageobacillus. However, additional empirical studies such as gene expression assays and knock-out experiments on selected proteins are needed to further elaborate the significance and relevance of the secreted proteins identified and described in this study.

\section{Conclusions}

This study provides the first comprehensive in silico exploration of the Geobacillus and Parageobacillus global secretome. The functional analysis of the 772 proteins that make up the combined secretome of the 64 strains used in this study revealed a functionally diverse group of species with a small core of 31 proteins that are involved in phylum-wide conserved processes such as sporulation, cell-wall biogenesis, and nutrient scavenging.

An exploration of the biotechnological potential of the combined secretome revealed several proteins with either a proven use in industrial processes or the potential to be applied in industrial or medical fields. However, while the identification of biotechnological candidates through orthology to known biocatalysts has revealed several target proteins in the secretome that warrant further research, these candidates might only represent the 'tip of the iceberg' of the biotechnological potential of the Geobacillus and Parageobacillus secretome, as a large percentage of the proteins in the secretome has yet to be characterized. As such, this study represents a framework from which the biotechnological potential of these two thermophilic genera can be further explored.

\section{Methods}

\section{Geobacillus and Parageobacillus genomes}

The genomes of 49 Geobacillus strains and 15 Parageobacillus strains were obtained from the GenBank assembly database [70] and the JGI IMG genome portal [71]. The genome assemblies were further improved as previously described [2]. The final dataset comprised twenty-two complete genomes and 42 high quality draft genomes (Table 1). Structural annotation of the genomes was performed using the SEED-based RAST server [72]. The core genome phylogeny of Geobacillus and Parageobacillus species was constructed as previously described by Aliyu et al. [2]. Briefly, core gene sets for Geobacillus and Parageobacillus species were aligned and concatenated, from which a maximum likelihood tree was constructed.

\section{Prediction of the global secretome}

The protein datasets derived from each genome were screened for secreted proteins using a combination of predictive software that scan for the presence/absence of signal peptides (SignalP v4.0 [73] and TatP [74]) as well as sub-cellular localization (PsortB 3.0 [27] and CELLO v.2.5 [75]). The location of the signal peptides was confirmed using PRED-TAT [76] and PRED_LIPO [77], and the presence of transmembrane domains was predicted using TMHMM [78]. The predicted secretion profiles of the different genomes were compared for number of shared orthologues using Proteinortho 5 [79] with the cut-off of $40 \%$ sequence identity, $50 \%$ sequence coverage, and e-value of $<1 \mathrm{e}-5$. Orthologous sequences were binned under unique identifiers and the global secretome was assembled by retaining representatives of each unique secreted protein. A presence/absence matrix was obtained by mapping each secretome against the global secretome, and secretomes were subsequently clustered into groups according to the number of shared orthologues. The percentage of shared orthology between secretion profiles was also calculated from the number of shared protein sequences, and these data were used to plot a UPGMA dendrogram using DendroUPGMA [80].

\section{Functional annotation of the global secretome}

The global secretome was re-annotated using NCBI Blast [81], Uniprot Blast [35], KAAS [33], and eggNOG mapper [82], which was also used to determine Conserved Orthologous Group functional categories [83]. Predicted secreted proteins were screened for the presence of conserved domains using Uniprot Blast, SMART [34] and the NCBI Conserved Domain Database using the Batch CD-Search algorithm [37]. Sequences were manually curated for biotechnologically relevant proteins using the databases described above, as well as scanned for carbohydrate active enzymes using the dbCAN Blast tool 
against the CAZY database [36] and for peptidases by BLAST search against the MEROPS database [63].

\section{Bacteria used for the enzyme activity assays}

The type strains of four Geobacillus (G. subterraneus DSM $13552^{\mathrm{T}}$, G. kaustophilus DSM $7263^{\mathrm{T}}$, G. stearothermophilus ATCC $12890^{\mathrm{T}}$, G. thermodenitrificans DSM $465^{\mathrm{T}}$ ) and four Parageobacillus (P. thermoglucosidasius DSM $2542^{\mathrm{T}}$, P. caldoxylosilyticus DSM $12041^{\mathrm{T}}$, P. toebii DSM $14590^{\mathrm{T}}$, and P. thermoantarcticus $\mathrm{M} 1^{\mathrm{T}}$ ) where provided by the Bacillus Genomic Stock Centre (D.R. Zeigler, Ohio State University, USA). All strains were routinely maintained in mLB media (10 g/l Tryptone, $5 \mathrm{~g} / \mathrm{l}$ Yeast Extract, $5 \mathrm{~g} / \mathrm{l} \mathrm{NaCl}$ ) with trace elements (1 mM Nitrilotrioacetic acid, $0.59 \mathrm{mM} \mathrm{MgSO}_{4} \cdot 7 \mathrm{H}_{2} \mathrm{O}$, $0.91 \mathrm{mM} \mathrm{CaCl} 2 \cdot 2 \mathrm{H}_{2} \mathrm{O}, 0.04 \mathrm{mM} \mathrm{FeSO}{ }_{4} \cdot 7 \mathrm{H}_{2} \mathrm{O}$ ) and incubated at $60^{\circ} \mathrm{C}$ and $150 \mathrm{rpm}$.

\section{Xylanase activity assays}

After overnight inoculation in mLB media a total of $500 \mu \mathrm{l}$ of each culture was transferred into $5 \mathrm{ml}$ of Oat Spelt (OS) Xylan media (10 g/l OS Xylan, $3 \mathrm{mM} \mathrm{K}_{2} \mathrm{HPO}_{4}$, $1.7 \mathrm{mM} \mathrm{KH}_{2} \mathrm{PO}_{4}, 6.25 \mathrm{mM} \mathrm{NH}_{4} \mathrm{NO}_{3}$, trace elements as described above) and grown at $60{ }^{\circ} \mathrm{C}$ and $150 \mathrm{rpm}$ for $16 \mathrm{~h}$. Supernatants were collected by centrifuging the cells at $6000 \mathrm{~g}$ for $5 \mathrm{~min}$, and subsequently used to measure the rates of xylan degradation. Xylan degradation rates were determined using the DNS method [84], where $250 \mu \mathrm{l}$ of sample was incubated with $750 \mu \mathrm{l}$ 3,5-dinitrosalicylic acid (DNSA) buffer (95 mM DNSA, $1 \mathrm{M}$ Potassium Sodium Tartrate, $0.5 \mathrm{M} \mathrm{NaOH}$ ) at $100{ }^{\circ} \mathrm{C}$ for $15 \mathrm{~min}$, after which the absorbance of each sample was measured at $540 \mathrm{~nm}$ using a MultiskanGO spectrophotometer (Thermo Scientific, USA). Absorbance measurements were performed for triplicate samples, and non-inoculated xylan media samples were used as negative controls. Activity (in nkat $\mathrm{ml}^{-1}$ ) was calculated by measuring the absorbance of each sample against a D-xylose standard curve. One nkat is defined as the amount of enzyme required to degrade one nmol of substrate under the stated conditions.

\section{Amylase activity assays}

Cultures were grown in $5 \mathrm{ml}$ of $\mathrm{mLB}$ for $16 \mathrm{~h}$ and the supernatant collected using the protocol described above. After collection, $150 \mu \mathrm{l}$ of supernatant of each culture was loaded into wells in $1 \%$ starch agar plates $(1 \% \mathrm{w} / \mathrm{v}$ soluble Starch, $2 \% \mathrm{w} / \mathrm{v}$ Agar). The plates were incubated for $16 \mathrm{~h}$ at $60{ }^{\circ} \mathrm{C}$ and subsequently stained with iodine tincture $(2.5 \% \mathrm{w} / \mathrm{v}$ Iodine, $2.5 \% \mathrm{w} / \mathrm{v}$ Potassium Iodine). A $30 \mathrm{mg} / \mathrm{ml}$ solution of alpha-amylase from Aspergillus oryzae (Sigma-Aldrich ${ }^{\circledR}$, Product code: 9001-19-8) in water was used as the positive control. Plates were incubated in triplicate, and activity was assessed by measuring zones of clearance in the stained plates.

\section{Lipase activity assays}

Lipase activity was inferred by measuring p-nitrophenyl butyrate (PNPB) degradation rates at $400 \mathrm{~nm}$. Cultures were grown for $16 \mathrm{~h}$ as described above, in a modified version of $\mathrm{mLB}$ to which $0.5 \%$ tributyrin was added before inoculation. Culture supernatants were recovered by centrifugation, and $100 \mu \mathrm{l}$ volumeswere resuspended in $900 \mu \mathrm{l}$ reaction buffer $\left(100 \mathrm{mM} \mathrm{NaH} \mathrm{PO}_{4}, 150 \mathrm{mM}\right.$ $\mathrm{NaCl}, 0.5 \%(\mathrm{v} / \mathrm{v})$ Triton X-100, pH 7.2). $10 \mu \mathrm{l}$ of $50 \mathrm{mM}$ PNPB was added and the absorbance $(400 \mathrm{~nm})$ measured every $30 \mathrm{~s}$ for $5 \mathrm{~min}$ at $60{ }^{\circ} \mathrm{C}$. Solution containing the reaction buffer, non-inoculated media and PNPB were used as negative controls. All measurements were performed in triplicates. The rate of PNPB degradation in units/ml enzyme was determined using the following equation:

$$
\text { Units } \mathrm{ml}^{-1} \text { enzyme }=\frac{\left(\Delta \mathrm{A}_{400 \mathrm{~nm}} / \mathrm{min} \text { sample }-\Delta \mathrm{A}_{400 \mathrm{~nm}} / \mathrm{min} \text { control }\right)(1.01)(\text { dilution factor })}{(0.0148)(0.1)}
$$




\section{Additional files}

Additional file 1: Table S1. Similarity matrix. Table showing the percentage of orthology between the secretomes of the 64 genomes used in this study. This similarity matrix was used to generate the orthology dendogram in Fig. 6.

Additional file 2: Table S2. Presence/absence matrix of the global secretome of Geobacillus and Parageobacillus. Table showing the presence or absence of the 772 protein sequences constituting the global secretome (annotated in the first row) across the 64 genomes used in this study (annotated in the first column). Presence/absence is indicated using a binary code of 1 and 0 to represent presence and absence, respectively.

Additional file 3: Figure S1. Distribution of GH families across the 51 glycoside hydrolases present in the global secretome. Pie-chart showing the distribution of glycoside hydrolase families in the global secretome of Geobacillus and Parageobacillus. The four most abundant families represented in the dataset include beta-galactosidases (GH2), alpha-amylases (GH13), chitinases (GH18), and lytic transglycosylases (GH23). The following families were also found to be present in the global secretome: GH1beta-glucosidases and beta-galactosidases; GH 3-beta-D-glucosidases, alpha-L-arabinofuranosidases; GH5-cellulases; GH10-endo-beta-1,3-xylanases; GH19-chitinases; GH25-chalaropsis-type lysozymes; GH27-alphagalactosidases and alpha-N-acetylgalactosaminidases; GH32-invertases; GH43-endo-alpha-L-arabinanases and beta-D-xylosidases; GH52-betaxylosidases; GH53-beta-1,4-galactanases; GH70-transglucosylases; GH73-beta-N-acetylglucosaminidases.

Additional file 4: Figure S2. Xylanase activity assay of Geobacillus and Parageobacillus type strains on Oat Spelt Xylan. Bar-plot showing the xylan degrading activity of the supernatant of selected Geobacillus and Parageobacillus strains, as measured using the DNS protocol [91]. The concentration of reduced sugars was determined by measuring the average absorbance of each sample against a xylose standard. Strains were labelled as follow: T1-P. thermoglucosidasius DSM 2542 ${ }^{\top} ; \mathrm{T} 2-\mathrm{G}$. subterraneus DSM 15332 ${ }^{\top}$;T3-P. caldoxylosilyticus DSM 12041 ${ }^{\top} ;$ T4-G. thermodenitrificans DSM 465 'T5-G. stearothermophilus ATCC $12980^{\top}$; T6-G. kaustophilus DSM $7263^{\top}$; T7-P. thermoantarcticus M1 ${ }^{\top}$; T8 - P. toebii DSM $14590^{\top}$.

Additional file 5: Figure S3. Qualitative amylase activity plate assays. Description of data: $1 \%$ Starch agar plates showing the starch-degrading activity of the supernatant of the Geobacilus and Parageobacillus strains tested. The plates were stained with iodine tincture $(2.5 \% \mathrm{w} / \mathrm{v}$ lodine, $2.5 \%$ Potassium lodide), and the areas of clearance represent starch degradation and corresponding amylase activity. The strains were labelled as described for Figure S2, and the positive control used in this assay $(+)$ is a-amylase from Aspergillus oryzae, provided by Sigma-Aldrich ${ }^{\circledR}$ (Product Code: 9001-19-8).

Additional file 6: Figure S4. PNPB Lipase activity assay of Geobacillus and Parageobacillus strains. Description of data: Bar-plot showing the degradation rates of PNPB by the supernatant of the eight Geobacillus and Parageobacillus strains tested. The labelling for the different strains is the same as described for Additional file 4: Figure S2.

Additional file 7: Table S3. Blast results for proteins with homology to biotechnologically relevant enzymes. Description of data: Table showing the blast results for the most significant hits between protein sequences from the global secretome and enzymes from the Uniprot database that have been previously highlighted as being of biotechnological relevance. The scores and e-values, as well as the accession numbers were obtained using the Blast function against the UniprotDB.

\section{Abbreviations}

TAT: twin-arginine translocation; T7SS: type VII secretion system; TM: transmembrane domains; CDSs: coding DNA sequences; KAAS: KEGG annotation server; SMART: Simple Modular Architecture Research Tool; CAZy: carbohydrate-active enzyme; TCBD: transporter classification database; SBPs: substrate-binding proteins; $\mathrm{GH}$ : glycoside hydrolase; $\mathrm{ROS}$ : reactive oxygen species; DNSA: 3,5-dinitrosalicylic acid; PNPB: p-nitrophenyl butyrate; OSX: oat spelt xylan.

\section{Authors' contributions}

PHL: performed the majority of the analyses described in this manuscript, including the design and implementation of the pipeline for the prediction and functional profiling of the global secretome, as well as wrote most of the manuscript. HA: performed the initial re-assembly and annotation of the Geobacillus and Parageobacillus genomes, and contributed to the writing and revision of the manuscript. DAC: contributed to the discussion, writing and revision of the manuscripts. PDM: contributed to the methodology design, discussion and suggestions during the work, and revised the final versions of the manuscript. All authors read and approved the final manuscript.

\section{Author details}

${ }^{1}$ Centre for Microbial Ecology and Genomics, Department of Biochemistry, Genetics and Microbiology, University of Pretoria, Pretoria, South Africa.

${ }^{2}$ Technical Biology, Institute of Process Engineering in Life Science, Karlsruhe Institute of Technology, Karlsruhe, Germany. ${ }^{3}$ School of Molecular and Cell Biology, University of Witwatersrand, Johannesburg, South Africa.

\section{Acknowledgements}

The authors wish to thank the University of Pretoria for their financial support.

\section{Competing interests}

The authors declare that they have no competing interests.

\section{Availability of data and materials}

All the genomes used in this study are available in the GenBank assembly database and the JGI IMG genome portal. The main datasets generated and analysed during the current study are included in the manuscript and supplementary data. Additional datasets generated during the current study are available from the corresponding author on reasonable request.

\section{Consent for publication}

Not applicable.

\section{Ethics approval and consent to participate}

Not applicable.

\section{Funding}

This study was funded through a University of Pretoria (UP) Postdoctoral Researcher fellowship.

\section{Publisher's Note}

Springer Nature remains neutral with regard to jurisdictional claims in published maps and institutional affiliations.

Received: 20 April 2018 Accepted: 26 September 2018

Published online: 03 October 2018

\section{References}

1. Nazina TN, Tourova TP, Poltaraus AB, Novikova EV, Grigoryan AA, Ivanova $A E$, et al. Taxonomic study of aerobic thermophilic bacilli:descriptions of Geobacillus subterraneus gen.nov., sp. nov. and Geobacillus uzenensis sp. nov. from petroleum reservoirs and transfer of Bacillus stearothermophilus, Bacillus thermocatenulatus, Bacillus thermoleovorans, Bacilluskaustophilus, Bacillus thermoglucosidasius and Bacillus thermodenitrificans to Geobacillus as the new combinations G. stearothermophilus, G. thermocatenulatus, G. thermoleovorans, G. kaustophilus, G. thermoglucosidasius and G. thermodenitrificans. Int J Syst Evol Microbiol. 2001;51(2):433-46.

2. Aliyu H, Lebre P, Blom J, Cowan D, De Maayer P. Phylogenomic reassessment of the thermophilic genus Geobacillus. Syst Appl Microbiol. 2016;39(8):527-33.

3. Zeigler DR. The Geobacillus paradox: why is a thermophilic bacterial genus so prevalent on a mesophilic planet? Microbiology. 2014;160:1-11. 
4. Hussein AH, Lisowska BK, Leak D. The genus Geobacillus and their biotechnological potential. Adv Appl Microbiol. 2015;92:1-48.

5. De Maayer P, Brumm PJ, Mead DA, Cowan DA. Comparative analysis of the Geobacillus hemicellulose utilization locus reveals a highly variable target for improved hemicellulolysis. BMC Genomics. 2014;15:836.

6. Anne J, Vrancken K, Van Mellaert L, Van Impe J, Bernaerts K. Protein secretion biotechnology in Gram-positive bacteria with special emphasis on Streptomyces lividans. Biochim Biophys Acta. 2014;1843(8):1750-61.

7. Schneewind O, Missiakas DM. Protein secretion and surface display in Gram-positive bacteria. Philos Trans R Soc Lond B Biol Sci. 2012;367(1592):1123-39.

8. Antelmann H, Tjalsma H, Voigt B, Ohlmeier S, Bron S, van Dijl J, et al. A proteomic view on genome-based signal peptide predictions. Genome Res. 2011;11(9):1484-502.

9. Tjalsma H, Antelmann H, Jongbloed JD, Braun PG, Darmon E, Dorenbos $\mathrm{R}$, et al. Proteomics of protein secretion by Bacillus subtilis: separating the "secrets" of the secretome. Microbiol Mol Biol Rev. 2004;68(2):207-33.

10. Zhou M, Theunissen D, Wels M, Siezen RJ. LAB-Secretome: a genomescale comparative analysis of the predicted extracellular and surfaceassociated proteins in lactic acid bacteria. BMC Genomics. 2010:11:651.

11. Lippolis R, Siciliano RA, Mazzeo MF, Abbrescia A, Gnoni A, Sardanelli AM, et al. Comparative secretome analysis of four isogenic Bacillus clausii probiotic strains. Proteome Sci. 2013;11:28.

12. Antranikian G, Egorova K. Extremophiles, a unique resource of biocatalysts for industrial biotechnology. In: Gerday C, Glansdorff N, eds. Physiology and biochemistry of extremophiles. American Society of Microbiology; 2007. p. 361-406.

13. Turner P, Mamo G, Karlsson EN. Potential and utilization of thermophiles and thermostable enzymes in biorefining. Microb Cell Fact. 2007:6:9.

14. Burton SG, Cowan DA, Woodley JM. The search for the ideal biocatalyst. Nat Biotechnol. 2002;20(1):37-45.

15. Diderichsen B, Poulsen GB, Jorgensen PL. Cloning and expression of an amylase gene from Bacillus stearothermophilus. Res Microbiol. 1991;142:793-6.

16. Rao JLUM, Satyanarayana T. Enhanced secretion and low temperature stabilization of a hyperthermostable and $\mathrm{Ca}^{2+}$-independent alpha-amylase of Geobacillus thermoleovorans by surfactants. Let. Appl Microbiol. 2003:36(4):191-6.

17. Rahman RN, Leow TC, Salleh AB, Basri M. Geobacillus zalihae sp. nov., a thermophilic lipolytic bacterium isolated from palm oil mill effluent in Malaysia. BMC Microbiol. 2007;7:77.

18. Fernandez-Arrojo L, Guazzaroni ME, Lopez-Cortes N, Beloqui A, Ferrer M. Metagenomic era for biocatalyst identification. Curr Opin Biotechnol. 2010;21(6):725-33.

19. Streit WR, Schmitz RA. Metagenomics-the key to the uncultured microbes. Curr Opin Microbiol. 2004;7(5):492-8.

20. Green ER, Mecsas J. Bacterial secretion systems-an overview. Microbiol Spectr. 2016;4(1):10. https://doi.org/10.1128/microbiolspec. VMBF-0012-2015.

21. Rigel NW, Braunstein M. A new twist on an old pathway-accessory Sec (corrected) systems. Mol Microbiol. 2008;69(2):291-302.

22. Goosens VJ, Monteferrante CG, van Dijl JM. The tat system of Gram-positive bacteria. Biochim Biophys Acta. 2014;1843(8):1698-706.

23. Sutcliffe IC. New insights into the distribution of WXG100 protein secretion systems. Antonie Van Leeuwenhoek. 2011;99(2):127-31.

24. Bottai D, Groschel MI, Brosch R. Type VII secretion systems in Gram-positive bacteria. Curr Top Microbiol Immunol. 2014;404:235-65.

25. Huppert LA, Ramsdell TL, Chase MR, Sarracino DA, Fortune SM, Burton BM. The ESX system in Bacillus subtilis mediates protein secretion. PLoS ONE. 2014;9(5):e96267.

26. Desvaux M, Hebraud M, Talon R, Henderson IR. Secretion and subcellular localization of bacterial proteins: a semantic awareness issue. Trends Microbiol. 2009;17(4):139.

27. Yu NY, Wagner JR, Laird MR, Melli G, Rey S, Lo R, et al. PSORTb 3.0: improved protein subcellular localization prediction with refined localization subcategories and predictive capabilities for all prokaryotes. Bioinformatics. 2010;26(13):1608-15.

28. Yamamoto $\mathrm{H}$, Kurosawa S, Sekiquchi J. Localization of the vegetative cell wall hydrolases LytC, LytE, and LytF on the Bacillus subtilis cell surface and stability of these enzymes to cell wall-bound or extracellular proteases. J Bacteriol. 2003;185(22):6666-77.

29. Yamaguchi H, Furuhata K, Fukushima T, Yamamoto H, Sekiguchi J. Characterization of a new Bacillus subtilis peptidoglycan hydrolase gene, yves (named cwlO), and the enzymatic properties of its encoded protein. J Biosci Bioeng. 2004;98(3):174-81.

30. Chastanet A, Losick R. Engulfment during sporulation in Bacillus subtilis is governed by a multi-protein complex containing tandemly acting autolysins. Mol Microbiol. 2007;64:139-52.

31. Grundy FJ, Henkin TM. Synthesis of serine, glycine, cysteine, and methionine. In: Sonenshein AL, Hoch JA, Losick R, editors. Bacillus subtilis and its closest relatives. Washington, D.C.: American Society for Microbiology; 2002. p. 245-54.

32. Minami H, Suzuki H, Kumagai H. y-Glutamultranspeptidase, but Not YwrD, is important in utilization of extracellular glutathione as a sulfur source in Bacillus subtilis. J Bacteriol. 2004;186(4):1213-4.

33. Moriya Y, Itoh M, Okuda S, Yoshizawa A, Kanehisa M. KAAS: an automatic genome annotation and pathway reconstruction server. Nucleic Acids Res. 2007;35:W182-5.

34. Schultz J, Milpetz F, Bork P, Ponting CP. SMART, a simple modular architecture research tool: identification of signaling domains. Proc Natl Acad Sci USA. 1998;95(11):5857-64.

35. The UniProt Consortium. UniProt: a hub for protein information. Nucleic Acids Res. 2015;43:D204-12

36. Cantarel BL, Coutinho PM, Rancuel C, Bernard T, Lombard V, Henrissat B. The carbohydrate-active enzymes database (CAZy): and expert resource for Glycogenomics. Nucleic Acids Res. 2009;37:D233-8.

37. Marchler-Bauer A, Derbyshire MK, Gonzales NR, Lu S, Chitsaz F, Geer LY, et al. CDD: NCBI's conserved domain database. Nucleic Acids Res. 2014;43(D1):D222-6.

38. Saier MH Jr, Reddy VS, Tsu BV, Ahmed MS, Li C, Moreno-Hagelsieb G. Transporter Classification Database (TCDB): recent advances. Nucleic Acids Res. 2016:44:D372-9.

39. Berntsson RPA, Smits SHJ, Schmitt L, Slotboom DJ. A structural classification of substrate-binding proteins. FEBS Lett. 2010;584(12):2606-17.

40. Riedel K, Lehner A. Identification of proteins involved in osmotic stress response in Enterobacter sakzakki by proteomics. Proteomics. 2007:7(8):1217-31.

41. Santos $H$, da Costa MS. Compatible solutes of organisms in hot saline environments. Environ Microbiol. 2002;4(9):501-9.

42. Takami H, Takaki Y, Chee GJ, Nishi S, Shimamura S, Suzuki H, et al. Thermoadaptation trait revealed by the genome sequence of thermophilic Geobacillus kaustophilus. Nucleic Acids Res. 2004;32(21):6292-303.

43. Shulami S, Gat O, Sonenshein AL, Shoham Y. The glucuronic acid utilization gene cluster from Bacillus stearothermophilus T-6. J Bacteriol. 1999;181(12):3695-704

44. Brumm PJ, De Maayer P, Mead DA, Cowan DA. Genomic analysis of six new Geobacillus strains reveals highly conserved carbohydrate degradation architectures and strategies. Front Microbiol. 2015:6:430.

45. Baba T, Shinke R, Nanmori T. Identification and characterization of clustered genes for thermostable xylan-degrading enzymes, beta-xylosidasee and xylanase, of Bacillus stearothermophilus 21. Appl Environ Microbiol. 1994:60(7):2252-8.

46. Zhang D, de Souza RF, Anantharaman V, Lyer LM, Aravind L. Polymorphic toxin systems: comprehensive characterization of trafficking modes, processing, mechanisms of action, immunity and ecology using comparative genomics. Biol Direct. 2012;7:18.

47. Ko TP, Liao CC, Ku WY, Chak KF, Yuan HS. The crystal structure of the DNase domain of colicin E7 in complex with its inhibitor Im7 protein. Structure. 1999:7(1):91-102.

48. Soelaiman S, Jakes K, Wu N, Li C, Shoham M. Crystal structure of colicin E3: implications for cell entry and ribosome inactivation. Mol Cell. 2001;8(5):1053-62.

49. Litzinger S, Duckworth A, Nitzsche K, Risinger C, Wittmann V, Mayer C. Muropeptide rescue in Bacillus subtilis involves sequential hydrolysis by $\beta$-N-acetylglucosaminidase and $\mathrm{N}$-acetylmuramyl-L-alanine amidase. J Bacteriol. 2010;192(12):3132-43.

50. Freiberg C, Fellay R, Bairoch A, Broughton WJ, Rosenthal A, Perret X. Molecular basis of symbiosis between rhizobium and legumes. Nature. 1997:387(6631):394-401. 
51. Salama R, Alalouf O, Tabachnikov O, Zolotnitsky G, Shoham G, Shoham Y. The abp gene in GeoBacillus stearothermophilus T-6 encodes a GH27 beta-L-arabinopyrosidase. FEBS Lett. 2012;586(16):2436-42.

52. Tabachnikov O, Shoham Y. Functional characterization of the galactan utilization system of GeoBacillus stearothermophilus. FEBS J. 2013;280(3):950-64.

53. de Souza PM, de Oliveira Magalhaes P. Application of microbial alphaamylase in industry — a review. Braz J Microbiol. 2010;41(4):850-61.

54. Nisha M, Satyanarayana T. Characterization of recombinant amylopullulanase (gt-apu) and truncated amylopullulanase (gt-apuT) of the extreme thermophile Geobacillus thermoleovorans NP33 and their action in starch saccharification. Appl Microbiol Biotechnol. 2013;97(14):6279-92.

55. Offen WA, Viksoe-Nielsen A, Borchert TV, Wilson KS, Davies GJ. Threedimensional structure of a variant "Termamyl-like" GeoBacillus stearothermophilus alpha-amylase at 1.9 A resolution. Acta Crystallogra F Struct Biol Commun. 2015;71:66-70

56. Christophersen C, Otzen DE, Noman BE, Chirstensen S, Schafer T. Enzymatic characterization of Novamyl ${ }^{\circledR}$, a thermostable alpha-amylase. Starch. 1998;50(1):39-45.

57. Jaeger KE, Ransac S, Dijkstra BW, Colson C, van Heuvel M, Misset O. Bacterial lipases. FEMS Microbiol Rev. 1994;15(1):29-63.

58. Houde A, kademi A, Leblanc D. Lipases and their industrial applications: an overview. Appl Biochem Biotechnol. 2004;118(1):155-70.

59. Hasan F, Shah AA, Hameed A. Industrial applications of microbial lipases. Enz Microb Technol. 2006;39(2):235-51.

60. Hamid TH, Eltaweel MA, Rahman RN, Basri M, Salleh AB. Characterization and solvent stable features of Strep-tagged purified recombinant lipase from thermostable and solvent tolerant Bacillus sp. strain 42. Ann Microbiol. 2009:59:111-8.

61. Waldersman C. Secretion, processing and activation of bacterial extracellular proteases. Mol Microbiol. 1989;3(12):1825-31.

62. Culp E, Wright GD. Bacterial proteases, untapped antimicrobial drug targets. J Antibiotechnol. 2017:70(4):366-77.

63. Rawlings ND, Barrett AJ, Bateman A. MEROPS: the peptidase database. Nucleic Acids Res. 2010;38:D227-33.

64. Gupta R, Beg QK, Lorenz P. Bacterial alkaline proteases: molecular approaches and industrial applications. Appl Microbiol Biotechnol. 2002:59(1):15-32.

65. Burgess EA, Wagner ID, Wiegel J. Thermal environments and biodiversity. In: Gerday C, Glansdorff N, editors. Physiology and biochemistry of extremophiles. American Society of Microbiology; 2007. p. 13-29.

66. Diaz JM, Hansel CM, Voelker BM, Mendes CM, Andeer PF, Zhang T. Widespread production of extracellular superoxide by heterotrophic bacteria. Science. 2013:340(6137):1223-6.

67. Studholme DJ. Some (bacilli) like it hot: genomics of Geobacillus species. Microbial Biotechnol. 2015;8(1):40-8
68. Sweeney MD, Xu F. Biomass converting enzymes as industrial biocatalysts for fuels and chemicals: recent developments. Catalysts. 2012;2(2):244-63.

69. Balciunas EM, Martinez FAC, Todorov SD, Franco BDGM, Converti A, Oliveira RPS. Novel biotechnological applications of bacteriocins: a review. Food Control. 2013;32(1):134-42.

70. Benson DA, Cavanaugh M, Karen C, Karsch-Mizrachi I, Lipman DJ, Ostell J, et al. GenBank. Nucleic Acids Res. 2013;41:D36-42.

71. Markowitz VM, Korzeniewski F, Palaniappan K, Szeto E, Werner G, Padki A, et al. The integrated microbial genomes (IMG) system. Nucleic Acid Res. 2006:34:D344-8.

72. Aziz RK, Bartels D, Best AA, DeJongh M, Disz T, Edwards RA, et al. The Rast Server: rapid annotations using subsystems technology. BMC Genomics. 2008:9:75.

73. Petersen TN, Brunak S, von Heijne G, Nielsen H. SignalP 4.0: discriminating signal peptides from transmembrane regions. Nat Methods. 2011;8(10):785-6.

74. Bendtsen JD, Nielsen H, Widdick D, Palmer T, Brunak S. Prediction of twinarginine signal peptides. BMC Bioinform. 2005;6:167.

75. Yu C-S, Lin C-J, Hwang J-K. Predicting subcellular localization of proteins for Gram-negative bacteria by support vector machines based on n-peptide compositions. Protein Sci. 2004;13(5):1402-6.

76. Bagos PG, Nikolaou EP, Liakopoulos TD, Tsirigos KD. Combined prediction of Tat and Sec signal peptides with hidden Markov models. Bioinformatics. 2010;26(22):2811-7.

77. Bagos PG, Tsirigos KD, Liakopoulos TD, Hamodrakas SJ. Prediction of lipoprotein signal peptides in Gram-positive bacteria with a hidden Markov model. J Proteome Res. 2008;7(12):5082-93.

78. Krogh A, Larsson B, von Heijne G, Sonnhammer EL. Predicting transmembrane protein topology with a hidden Markov model: application to complete genomes. J Mol Biol. 2001;305(3):567-80.

79. Lechner M, FindeiB S, Steiner L, Marz M, Stadler F, Prahaska SJ. Proteinortho: detection of (Co-)orthologs in large-scale analysis. BMC Bioinform. 2011;12:124

80. Garcia-Vallvé S, Puigbo PERE. DendroUPGMA: a dendrogram construction utility. Universitat Rovira i Virgili (2009).

81. Johnson M, Zaretskaya I, Raytselis Y, McGinnis S, Madden TL. NCBI BLAST: a better wed interface. Nucleic Acid Res. 2008;36:W5-9.

82. Huerta-Cepas J, Forslund K, Coelho LP, Szklarczyk D, Jensen LJ, von Mering $C$, et al. Fast genome-wide functional annotation through orthology assignment by eggNOG-Mapper. Mol Biol Evol. 2017;34(8):2115-22.

83. Tatusov RL, Fedorova ND, Jackson JD, Jacobs AR, Kiryutin B, Koonin EV, et al. The COG database: an updated version includes eukaryotes. BMC Bioinform. 2003;4:41.

84. Miller GL. Use of dinitrosalicylic acid reagent for determination of reducing sugar. Anal Chem. 1959;31(3):426-8.
Ready to submit your research? Choose BMC and benefit from:

- fast, convenient online submission

- thorough peer review by experienced researchers in your field

- rapid publication on acceptance

- support for research data, including large and complex data types

- gold Open Access which fosters wider collaboration and increased citations

- maximum visibility for your research: over 100M website views per year

At BMC, research is always in progress.

Learn more biomedcentral.com/submissions 